\title{
A choice of death - the signal-transduction of immune-mediated beta-cell apoptosis
}

\author{
D. L. Eizirik ${ }^{1}$, T.Mandrup-Poulsen ${ }^{2}$ \\ ${ }^{1}$ Gene Expression Unit, Diabetes Research Center, Vrije Universiteit Brussel, Brussels, Belgium \\ ${ }^{2}$ Steno Diabetes Center, Gentofte, Denmark
}

Abstract

Apoptosis is likely to be the main form of beta-cell death in immune-mediated diabetes mellitus in rodents and possibly in humans. Clarification of the regulation of beta-cell death could indicate novel sites for therapeutic intervention in Type I (insulindependent) diabetes mellitus. We review the molecular effectors and signal transduction of immune-mediated beta-cell apoptosis.

Data obtained on non-obese diabetic (NOD) mice suggest that macrophages and $\mathrm{CD} 4^{+} \mathrm{T}$-cells are the main cellular effectors, whereas $\mathrm{CD}^{+} \mathrm{T}$-cells are more important initiators of the immune process leading to beta-cell death. Perforin could be the effector molecule utilized by $\mathrm{CD} 8^{+}$T-cell initiation, whereas $\mathrm{CD}^{+}$mediated beta-cell destruction is mostly dependent on Fas/FasL and the cytokines IFN $\gamma$ and TNF- $\alpha$.

The macrophage cytokine IL- $1 \beta$ in combination with IFN- $\gamma$ and TNF- $\alpha$, plays an important role for beta-cell dysfunction and death. Signal transduction by these cytokines involves: (i) binding to specific receptors, (ii) signal transduction by cytosolic kinases (especially the so-called mitogen- and stress-activated protein kinases) and/or phosphatases, (iii) mobilization of diverse transcription factors - with nuclear factor $\varkappa \mathrm{B}(\mathrm{NF}-\varkappa \mathrm{B}), \mathrm{AP}-1$ and STAT-1 probably playing key roles for beta-cell apoptosis; (iv) up-regulation or down-regulation of gene transcription. Recent data obtained by microarray and proteomic analysis suggest that the process of beta-cell apoptosis depends on the parallel and/or sequential up-regulation and down-regulation of considerable numbers of genes, which can be grouped in gene modules or patterns according to their functions. A detailed characterization of these "gene modules", and of the signalling pathways and transcription factors regulating them could allow us to understand the ultimate mechanisms leading to beta-cell apoptosis. [Diabetologia (2001) 44: 2115-2133]

Keywords Beta cell, apoptosis, interleukin-1, interferon- $\gamma$, nitric oxide, diabetes mellitus.
Received: 18 June 2001 and in revised form: 6 August 2001

Corresponding author: D.L.Eizirik, Gene Expression Unit, Diabetes Research Center, Vrije Universiteit Brussel, Laarbeeklaan 103, Brussels, Belgium, e-mail: deizirik@mebo.vub. ac.be

Abbreviations: AP-1, Activator protein 1; ATF-2, activating transcription factor 2; CD, cluster of differentiation; ds, double-stranded; ERK, extracellular signal-regulated kinase; FACS, fluorescence activated cell sorting; FADD, Fas activated death domain; GIP, gastric inhibitory peptide; GLUT, glucose transporter; IB-1, islet brain 1 ; IFN $\gamma$ interferon- $\gamma$; IKK, $\varkappa \mathrm{B}$ kinase; IL- $1 \beta$ interleukin- $1 \beta$; IL-1R, interleukin- 1 receptor;
IL-1Ra, interleukin-1 receptor antagonist; iNOS, inducible nitric oxide synthase; IRAK, interleukin-1 receptor activated kinase; IRF-1, interferon regulatory factor 1; JAK, Janus protein tyrosine kinase; JBD, JNK binding domain of IB-1; JNK, c-jun N-terminal kinase; MAPK, mitogen-activated protein kinase; MnSOD, Mn superoxide dismutase; NF- $\varkappa \mathrm{B}$, nuclear factor$\varkappa \mathrm{B}$; NIK, NFxB inducing kinase; NOD, non-obese diabetic; $\mathrm{PKB}$, protein kinase $\mathrm{B}$; PKC, protein kinase $\mathrm{C}$; PKR, protein kinase R; RIP, rat insulin promoter; STAT, signal transducers/ activators of transcription; TNF, tumour necrosis factor; TRADD, TNF receptor associated death domain; TRAF, TNF receptor associated factor; TRAIL, TNF related apoptosis inducing ligand 
The term apoptosis, or programmed cell death, is used to describe the regulated disposal of a cell. Following signals delivered by cell surface ligands, viral infection, cytokines, absence of supporting growth factors etc, the target cells shrink and go through a process which includes chromatin condensation, protein cleavage, DNA degradation, fragmentation into membrane-bound apoptotic bodies and phagocytosis by neighbouring cells, with little or no inflammatory response. Apoptotic cell death contrasts with necrotic, or accidental cell death, which is usually triggered by acute loss of cell homeostasis. Necrosis leads to cellular swelling, early plasma membrane rupture and disruption of cellular organelles. The resulting leakage of intracellular contents causes local inflammatory response. The morphology of beta cell apoptosis and necrosis has been previously reviewed [1].

Recent evidence points to apoptosis as the main form of beta-cell death in animal models of Type I (insulin dependent) diabetes mellitus [2]. This raised the possibility that human beta cells also die by apoptosis in early Type I diabetes which has instigated more than 200 studies addressing beta-cell apoptosis since 1993 . But, why bother with the mode by which beta-cells are killed? They will be gone anyway and the patients will become insulin-dependent for life, independently from the fact that his/her beta-cells died by apoptosis or necrosis. The main reasons for the increasing interest in this field are that: firstly, identification of the form of cell death in Type I diabetes could provide valuable clues for the cause of cell death; and secondly, apoptosis can be arrested at early checkpoints, often allowing preservation of cell function [3]. Thus, elucidation of the process of betacell death and of the cell-death machinery in these cells, could disclose multiple sites for therapeutic intervention in Type I diabetes.

Recent reviews have addressed different aspects of beta-cell apoptosis, both in Type I and Type II (non-insulin-dependent) diabetes mellitus, and during development $[1,2,4-8]$. We focus on the molecular effectors and signal-transduction of immune-mediated beta-cell apoptosis, with special emphasis on recent developments in the field.

\section{Beta-cell apoptosis in experimental and clinical Type I diabetes mellitus}

Apoptosis is mostly asynchronous. The cells undergoing apoptosis show a number of "eat-me" flags, such as modifications in surface sugars or exposure of inner-membrane phosphatidylserines, leading to early phagocytosis by neighbouring cells or by professional scavengers of the macrophage line $[9,10]$. For instance, the clearance of apoptotic beta cells in NOD mice has been estimated to be executed in the range of 1.7 [11] to $11 \mathrm{~min}$ [12]. These characteristics make it very difficult to detect apoptotic cells in vivo in NOD mice or BB rats, two animal models of Type I diabetes where the process of beta-cell destruction takes days to weeks and makes it nearly impossible to detect apoptotic cells in the pancreata of Type I diabetes patients in whom beta-cell destruction could proceed for several months or years.

Despite these difficulties, beta-cell apoptosis has been shown in both spontaneous $[12,13]$ and accelerated $[11,14,15]$ diabetes in NOD mice, detected by the deoxynucleotide transferase (TdT)-mediated dUTP nick-end labelling (TUNEL) method. Betacell apoptosis was also observed in the multiple lowdose streptozotocin model in mice (an animal model where diabetes is triggered by both toxic and immune components) [16] and in transgenic mice expressing interferon- $\gamma$ (IFN $\gamma)$, under the control of the rat glucagon promoter [17]. In the latter model, beta-cell apoptosis was compensated by vigorous regeneration, and most animals did not develop hyperglycaemia [17]. A large proportion of apoptotic cells in and around the islets are infiltrating T cells $[12,14]$, which emphasizes the need to carefully identify the cells undergoing cell death by double-staining with insulin.

Of note, beta-cell apoptosis is present in diabetesprone NOD mice prior to light-microscopically evident T-cell infiltration [13], suggesting that initial beta-cell death in this model is triggered by a few infiltrating T-cells and/or soluble mediators released by macrophages, the first cells to infiltrate the islets [18]. The time course of beta-cell apoptosis was further investigated by a study with serial biopsies carried out in diabetes prone and diabetes resistant BB rats [19]. Islet cell apoptosis was initially detected at 68 days of age in the diabetes prone and diabetes resistant $\mathrm{BB}$ rats, correlating with early insulitis and a decrease in pancreatic insulin staining. A further increase in islet apoptosis was present in the diabetes prone, but not in the diabetes resistant BB rats, at 85 days, coinciding with the onset of diabetes [19]. Although the authors showed histological evidence that some of the cells undergoing apoptosis were insulin positive, there was no double-staining for insulin in the preparations used to determine the number of apoptotic cells in islets. It is thus not clear if the majority of cells undergoing apoptosis are indeed beta-cells.

The observations described above suggest that apoptosis is the main, but probably not the only, form of beta-cell death in animal models of autoimmune diabetes; necrosis could also be involved. Much less information is available regarding human Type I diabetes. Thus, whereas one study claimed that apoptosis was observed in beta-cells from two young patients who died in ketoacidosis after diagnosis of Type I diabetes [20], this was not confirmed in a subsequent study of pancreas biopsy specimens from 13 recentonset diabetic patients [21]. Both studies showed evi- 
dence of Fas expression in the beta-cells, while FasL was present on infiltrating mononuclear cells [20, 21]. In other words, while both studies showed evidence of the presence of the "murder weapon", only one of them was able to present the corpse. This is not surprising, taking into account the difficulties in identifying apoptotic cells in the course of a long-lasting autoimmune assault.

\section{The in vivo effectors of beta-cell apoptosis}

The immune system utilizes various mechanisms to eliminate target cells for host defence against infectious agents and malignant transformation, but also as part of autoimmune disease. It is widely accepted that macrophages and T-cells are important effector cells leading to beta-cell destruction, whereas betacell autoreactive antibodies play a minor if any function [18]. Macrophages can induce target cell apoptosis via the synthesis of proinflammatory cytokines, such as IL-1 and TNFo, as well as nitric oxide and other free radicals. Activated T-cells produce apoptosis-inducing cytokines such as $\mathrm{TNF} \alpha$, lymphotoxin and IFN $\gamma$. T-cells also express the ligand of the Fas receptor (Fas ligand - FasL) and the tumour necrosis factor related apoptosis inducing ligand (TRAIL), both leading to apoptosis via activation of effector caspases. In addition, $\mathrm{CD}^{+}$cytotoxic T-cells have cytolytic granules containing perforin, which are released after the T-cell receptor is triggered. Perforin polymers are inserted into the target cell membrane as tubular pore complexes, allowing access of granzyme, another constituent of the cytotoxic T-cell granules, to the cytosol of the target cell. Granzyme is a protease that, upon cellular entry via the tubular pore complexes, activates nucleases and caspases leading to cell death [22].

We review recent evidence obtained mostly in NOD mice regarding the relative importance of $\mathrm{CD}^{+}$and $\mathrm{CD}^{+}{ }^{+}$-cells as effector cells, and the putative role of Fas, the perforin-granzyme system and proinflammatory cytokines as mediators of beta-cell apoptosis. There is only limited information from studies on human Type I diabetes addressing these questions and caution should be exerted when extrapolating the reviewed animal-model data to the disease in humans.

Effector cells. It is unquestionable that T-cells are necessary for beta-cell destruction in animal models of Type I diabetes, but the relative role of the CD4 and CD8 T-cell subsets and the precise mechanisms by which these T-cells exert their effector function is not clear [23]. Convincing evidence points to the crucial importance of the $\mathrm{CD}^{+}$helper T-cells in the autoimmune pathogenesis of diabetes [24]. Thus, diabetic islet specific $\mathrm{CD}^{+}$, but not $\mathrm{CD}^{+} \mathrm{T}$-cell clones, are capable of transferring diabetes [25]. Further, $\mathrm{CD}^{+}$T-cells destroy islet beta-cells in the absence of $\mathrm{CD}^{+} \mathrm{T}$-cells, as demonstrated in studies of disease recurrence in syngeneic and allogeneic islet grafts transplanted to spontaneously diabetic NOD mice [26]. Moreover, NOD scid transgenic mice devoid of $\mathrm{CD}^{+} \mathrm{T}$-cells or B-lymphocytes, but carrying a betacell specific T-cell receptor on $\mathrm{CD}^{+}{ }^{+} \mathrm{T}$-cells, develop accelerated diabetes [11], whereas CD4 ${ }^{\text {null }}$ NOD mice do not develop the disease [27]. Additional studies, however, suggest an important role for $\mathrm{CD}^{+}$ T-cells in diabetes immunopathogenesis. Thus, firstly, depleting anti-CD8 antibodies retard the development of diabetes in NOD mice [28]; secondly, transfer of diabetes by non-activated $\mathrm{CD} 4^{+} \mathrm{T}$-cells from prediabetic NOD mice requires CD8 ${ }^{+}$T-cells [29]; thirdly, mutation of the beta-2 microglobulin component of the major histocompatibility complex Class I molecule, which abrogates $\mathrm{CD}^{+}$T-cell antigen recognition, prevents transfer of diabetes by non-activated NOD splenocytes [30]; and fourthly, $\mathrm{CD}^{+}$T-cells were found to be important for initiating the disease, but not for the final effector phase [30, 31].

Macrophages are an absolute requirement for the development of Type I diabetes in animal models [18]. Thus, depletion of macrophages or prevention of islet invasion by macrophages prevents diabetes $[32,33]$. Macrophages might be required for the development of diabetes as antigen-presenting cells; as providers of costimulatory signals for other effector cells; and as effector cells by the production of inflammatory mediators such as cytokines, free radicals, or proteases. Several studies have suggested that macrophages from spontaneously diabetic NOD mice are defective in the ability to present antigen $[34,35]$. Therefore B-lymphocytes [36] or dendritic cells [37] are more important antigen-presenting cells. In contrast, there is evidence that macrophages provide important costimulatory signals for T-cell activation [38-40]. The effector capabilities of macrophages via IL-1 and tumour necrosis factor (TNF) production, as well as by the release of free oxygen and nitric oxide radicals are well documented [41].

In summary, macrophages are required and activated $\mathrm{CD}^{+}{ }^{+} \mathrm{T}$-cell are both necessary and sufficient in causing the disease, whereas $\mathrm{CD}^{+} \mathrm{T}$-cell clones are necessary but usually not sufficient to cause beta-cell destruction. Only after appropriate co-stimulation or in unique transgenic T-cell receptors [27, 42], are $\mathrm{CD}^{+} \mathrm{T}$-cells sufficient in causing Type I diabetes. The precise mechanisms by which $\mathrm{CD} 8^{+} \mathrm{T}$-cells provide the initiating signal to the $\mathrm{CD} 4^{+} \mathrm{T}$-cells are currently not known.

The role of the perforin/granzyme system as effector mechanism. The available findings on the perforingranzyme effector system are somewhat contradictory and often dependent on the experimental model 
Table 1. Evidence in favour (Pro) and against (Con) a role for the Fas/FasL system in immune-mediated beta-cell death

\begin{tabular}{|c|c|}
\hline Fas/FasL: Pro & Fas/FasL: Con \\
\hline - IL-1 induces beta cells to express Fas [51] & No Fas/FasL expression on beta cells isolated from NOD mice [58] \\
\hline $\begin{array}{l}\text { - Beta -cell Fas, IL-1, TNF- } \alpha \text { and IFN } \gamma \text {, but not FasL expression } \\
\text { correlates with beta-cell destruction [52] }\end{array}$ & $\begin{array}{l}\text { Fas-deficient islet grafts are not protected against destruction in } \\
\text { NOD mice [59] or after adoptive transfer [60] }\end{array}$ \\
\hline $\begin{array}{l}\text { - CD4 } 4.1 \text { beta-cell specific TCR expressing T-cells kill beta cells } \\
\text { expressing Fas after in vitro cytokine exposure, but do not kill } \\
\text { Fas negative beta cells [45] }\end{array}$ & Anti-FasL antibody fails to prevent NOD diabetes [15] \\
\hline $\begin{array}{l}\text { - Fas-negative NOD lpr/lpr mice are resistant to spontaneous or } \\
\text { adoptively transferred diabetes }[54,55]\end{array}$ & $\begin{array}{l}\text { FasL }+ \text { T-cells prevent adoptive transfer of diabetes, which is re- } \\
\text { versed by anti-FasL antibody [61] }\end{array}$ \\
\hline $\begin{array}{l}\text { - RIP-FasL transgenic NOD mice have increased diabetes inci- } \\
\text { dence [56] due to neutrophilic infiltration [54] }\end{array}$ & $\begin{array}{l}\text { Soluble FasL mimic the effect of FasL }{ }^{+} \text {T-cells and reduces memory } \\
\text { cells by apoptosis [48] }\end{array}$ \\
\hline \multicolumn{2}{|l|}{ - Reduced T-cell FasL expression prevents NOD diabetes [57] } \\
\hline
\end{tabular}

utilized. Naive beta-cells are resistant to cytolytic Tcell-mediated perforin-dependent killing in vitro, but they become sensitive after cytokine-induced upregulation of MHC Class I molecules [43]. It is questionable whether $\mathrm{CD} 4^{+} \mathrm{T}$-cells can kill beta-cells by the perforin system, as this mechanism is dependent on MHC Class II recognition of the target cell and beta cells probably do not express MHC Class II. Accordingly, beta-cell killing by $\mathrm{CD}^{+}$and $\mathrm{CD} 8^{+} \mathrm{T}$-cells expressing the diabetogenic 4.1 or $8.3 \mathrm{~T}$-cell receptor clonotypes respectively is perforin-independent [44, 45].

The available in vivo data on perforin are highly model-dependent. Thus, both in transgenic mice expressing the Lymphocytic Choriomeningitis virus glycoprotein under the control of the rat insulin promoter (RIP) and in the $8.3 \mathrm{~T}$-cell receptor $\mathrm{CD}^{+} \mathrm{T}$-cell mediated diabetes, beta-cell death is perforin-independent $[44,46,47]$. In contrast, $\mathrm{CD} 8^{+}$killing of beta cells in transgenic mice expressing the Influenza virus hemagglutinin under the RIP is dependent on perforin [48]. Furthermore, in double transgenic mice expressing TNF- $\alpha$ and the T-cell costimulatory molecule B7-1 under the control of the RIP, the development of diabetes is independent of perforin and Fas [49]. In a less artificial model, however, perforin deficient NOD mice have reduced incidence and delayed onset of Type I diabetes [50].

This evidence suggests that beta-cell killing in NOD diabetes is partially dependent on perforin-mediated beta-cell killing by $\mathrm{CD} 8^{+} \mathrm{T}$-cells. It remains to be established whether the putative initiating role of $\mathrm{CD}^{+} \mathrm{T}$-cells also involves perforin as an effector mechanism.

The Fas/FasL effector system. In vitro data led to the suggestion that Fas receptor is induced by cytokines (mostly IL-1) in beta cells, marking them for killing mediated by $\mathrm{CD}^{+}$(initiating phase) or $\mathrm{CD}^{+}{ }^{+} \mathrm{T}$-cells (later effector phase) expressing FasL [20, 21, 51]. However, even after several years of intense studies (Table 1) [15, 45, 48, 51-61] the involvement of Fas/ FasL as effector molecules for beta-cell destruction in Type I diabetes remains controversial.

In vitro studies have shown that T-cell-mediated Fas-dependent killing can occur in cultured beta cells [45], whereas histological data indicate that Fas expression is up-regulated in human and rodent beta cells in early Type I diabetes [20, 21, 52, 53]. In contrast, functional in vivo studies question if the main role of Fas is exerted at the target beta cell. Thus, Fas-deficient islet grafts are not protected against the destruction in NOD mice or after adoptive transfer $[59,60]$. In these models, however, beta cells are exposed to a fully activated autoimmune response, which could use other mediators to destroy them. Thus, these experiments do not exclude that Fas/ FasL could play a role in insulitis, as suggested by experiments with $\mathrm{CD} 8^{+}$and $\mathrm{CD} 4^{+}$mediated diabetes in perforin-deficient mice $[44,45]$ but they show that sufficient beta-cell effectors operate independent of Fas/FasL. Some studies involving the manipulation of the Fas/FasL system in animal models are difficult to interpret because of the effects of this manipulation on the $\mathrm{CD}^{+}$and $\mathrm{CD}^{+}$, bystander suppressor cells as well as target beta cells. Present evidence (Table 1), which requires further study, indicates mainly an immunoregulatory and, to a lesser degree, a betacell effector function of Fas/FasL. The importance of TRAIL and membrane-bound TNF should also be investigated further as candidates of T-cell effector mechanisms [49, 60, 62].

Inflammatory mediators and beta-cell death. As previously reviewed [18], attempts to clarify the effector role of cytokines by systemic administration have 
Table 2. Transgenic expression of cytokines in islets of non-diabetes-prone animals

\begin{tabular}{|c|c|c|c|}
\hline Cytokine & Pancreatitis & Insulitis & Diabetes \\
\hline Interferon $\alpha[65]$ & - & + & + \\
\hline Interferon $\gamma[64]$ & + & + & + \\
\hline Interferon $\gamma[17](\alpha$-cell) & & - & $\begin{array}{l}\text { - (apopto- } \\
\text { sis/regen- } \\
\text { eration) }\end{array}$ \\
\hline Interleukin-2 [66] & + & + & - \\
\hline Interleukin-6 [67] & & $-1+$ & - \\
\hline TNF- $\alpha[68]$ & - & + & - \\
\hline B7-1 [63] & & - & - \\
\hline TNF- $\alpha / \mathrm{B} 7-1[63]$ & & + & + \\
\hline TNF- $\beta$ [69] & - & perinsulitis & - \\
\hline Interleukin-10 [70] & + & - & - \\
\hline
\end{tabular}

Table 3. Transgenic expression of cytokines in islet cells in NOD mice

\begin{tabular}{lllll}
\hline & Age & Cell & Insulitis & Diabetes \\
\hline TNF $\alpha$ [71] & Adults & $\alpha$ & $\uparrow \uparrow$ & $\downarrow$ \\
TNF $\alpha$ [72] & Neonates & $\beta$ & & $\uparrow$ \\
TNF $\alpha$ Tet/RIPB7-1 [73] & 25 days & $\beta$ & & $\uparrow$ \\
IL-2 [74] & & $\beta$ & $\downarrow$ & $\uparrow$ \\
IL-4 [75, 76] & & & $\downarrow$ & $\downarrow$ \\
IL-10 [77] & & $\beta$ & & $\uparrow$ \\
\hline
\end{tabular}

Table 4. Systemic cytokine-deficient NOD mice models

\begin{tabular}{ll}
\hline Deficiency & Protection vs diabetes \\
\hline IFN $\gamma[82]$ & - \\
IFN $\gamma$ receptor $\alpha$-chain $[46]$ & + \\
IFN $\gamma$ receptor $\beta$-chain $[43,83]$ & - \\
IL-1 [84] & - \\
IL-4 [85] & - \\
IL-4 receptor $[86,87]$ & + \\
\hline
\end{tabular}

been highly contentious. In contrast, anti-cytokine intervention using antibodies or soluble receptors against IL-1, IL-6, TNF $\alpha$ and IFN $\gamma$ have almost unanimously shown inhibitory effects on diabetes in NOD mice and $\mathrm{BB}$ rats [18].

In recent years, transgenic techniques have been used in an attempt to clarify the role of locally produced cytokines in beta-cell destruction. We list experiments [17, 63-70] where cytokine transgenes have been introduced into beta cells of non-diabetes-prone animals (Table 2). Only mice with IFN- $\alpha / \gamma$ or TNF/B7- transgenic expression developed both insulitis and diabetes. It could be argued, however, that these studies are hampered by the fact that the transgene is introduced into animals not genetically predisposed to develop diabetes. We list the evidence where cytokine transgenes have been introduced into beta cells of NOD mice (Table 3) [71-77]. Betacell IL-2 expression accelerated NOD diabetes, prob- ably by stimulating CD4 ${ }^{+}$T-cells [74]. In NOD mice with transgenic expression of TNF $\alpha$ in beta cells, the incidence of diabetes was either increased or decreased depending on the age of the animals at which the transgene was activated. This emphasizes that inflammatory mediators could have very diverse effects depending on the location of action and time- and concentration-windows.

Transgenic mice expressing IFN- $\gamma$ under the control of RIP have severe insulitis and destruction of pancreatic beta cells $[64,78,79]$. Treatment with anti-IFN- $\gamma$ prevents diabetes in IFN- $\gamma$ transgenic [80] mice. It is not clear whether these effects of IFN- $\gamma$ are due to: firstly, induction of MHC class I and II expression in infiltrated islets, enhancing CTL-mediated beta-cell damage; secondly, local or systemic effects on the immune system; thirdly, direct cytotoxic effects of the beta cells; and fourthly, any combinations of these effects. Transgenic NOD mice expressing a dominant negative mutant-IFN- $\gamma$ receptor in beta cells develop diabetes similarly to wild type animals [79], and islets from IFN- $\gamma$ receptor $\mathrm{KO}$ are destroyed after allograft transplantation [81], suggesting that IFN- $\gamma$ alone plays a minor direct role in beta-cell damage. However, beta-cell destruction in virus-induced diabetes requires effects of IFN- $\gamma$ on the beta cell [43]. Thus, it seems that the role of IFN- $\gamma$ for immune-mediated beta-cell death varies depending on the animal models utilized.

Diabetes in the RIP-TNF $\alpha / \mathrm{B} 7-1$ model is mainly caused by co-stimulation of $\mathrm{CD} 8^{+} \mathrm{T}$-cells and thereby breakdown of tolerance [73] but the relevance of this model is not clear, because beta cells are not known to express B7-1. IL-10 beta cell transgenics seem to have an increased incidence of diabetes via chemokine, especially ICAM-dependent, potentiation of islet inflammation [70].

Overexpression studies can be criticized for eliciting numerous secondary effects and therefore several investigators have attempted to create systemically cytokine-deficient NOD mice (Table 4) [43, 46, 82-87]. Of note, NOD mice deficient in the signalling beta-chain of the IFN receptor were not protected against diabetes development [84], whereas disruption of the ligand-binding $\alpha$-chain of the IFN- $\gamma$ receptor was protective [83]. This protective effect is given by a closely located hitherto unidentified diabetes resistance allele [88].

The ability of responding to IL-4, tested either by introducing IL-4 ${ }^{\text {null }}$ mutation into NOD mice carrying rearranged T-cell receptor genes from a diabetogenic T-cell clone or by targeted mutation of the IL-4 receptor $\alpha$-gene in the RIP Influenza virus haemagglutinin model, led to different results (Table 4). An explanation for this contradiction has not been found but it has been suggested that IL-4 is not exclusively a "protective" cytokine since IL-4 can trigger autoim- 
mune diabetes by increasing self-antigen presentation by dendritic cells within the pancreatic islets [89].

Clear conclusions are difficult to draw from the above cited studies. It should be kept in mind that the outcome of cytokine transgenic models is highly dependent upon whether local or systemic expression or knock-out is used and whether life-long versus time-defined expression or knock-out is obtained. Redundancy, compensatory mechanisms and secondary pathology must be considered [90]. Thus, single cytokine transgenic studies may only give limited information on the in vivo relevance of the local role of cytokines as effectors of beta-cell destruction. Furthermore, neither IL-1 nor cytokine combination overexpression and/or knock-out studies have been reported.

The studies reviewed above suggest that $\mathrm{CD} 8^{+} \mathrm{T}-$ cells participate in initiating the beta-cell destructive process via perforin-dependent or Fas-dependent mechanisms. In the later effector phase, a combination of beta-cell killing mediated by inflammatory cytokines and $\mathrm{CD}^{+}$cells, probably via the Fas/FasL system or by membrane bound TNF/TRAIL is involved $[49,60,62]$.

\section{The signal transduction of beta-cell death - in vitro studies}

Cytokine-induced beta-cell death. Following the original description of the inhibitory effects of IL-1 on rat islet function [91], several studies have shown that this cytokine, alone or in combination with IFN- $\gamma$ and TNF- $\alpha$ leads to islet-cell dysfunction and death $[18,92]$. Exposure of fluorescence activated cell sorting (FACS)-purified rat and mouse beta cells to interleukin- $1 \beta$ (IL- $1 \beta$ ), in combination with IFN- $\gamma$ and/or $\mathrm{TNF}-\alpha$, leads to cell death by necrosis and predominantly by apoptosis [93-97]. Of note, the full proapoptotic effect of cytokines in rat beta cells is already achieved at relatively low concentrations of cytokines $(10 \mathrm{U} / \mathrm{ml} \mathrm{IL}-1 \beta+100 \mathrm{U} / \mathrm{ml} \mathrm{IFN}-\gamma)$ and higher concentrations of IL- $1 \beta+$ IFN- $\gamma$ fail to further increase the number of apoptotic cells (Fig. 1). Similar results were observed with the necrosis index, which reached a significant increase compared to control beta cells already at IL- $1 \beta 10 \mathrm{U} / \mathrm{ml}+\mathrm{IFN}-\gamma 100$ $\mathrm{U} / \mathrm{ml}(33 \pm 5)$ and did not increase further when the higher cytokine concentrations were tested (data not shown). This suggests that primary beta cells have a limited number of cytokine receptors and do not further increase beta cell death once these are occupied by higher cytokine concentrations. The necrotic component of beta-cell death is probably related to nitric oxide production, because it is abolished in mice genetically inducible nitric oxide synthase deficient $\left(\mathrm{iNOS}^{-l_{-}}\right.$or iNOS KO), whereas cytokine-induced apoptosis is delayed but not prevented [95, 98].

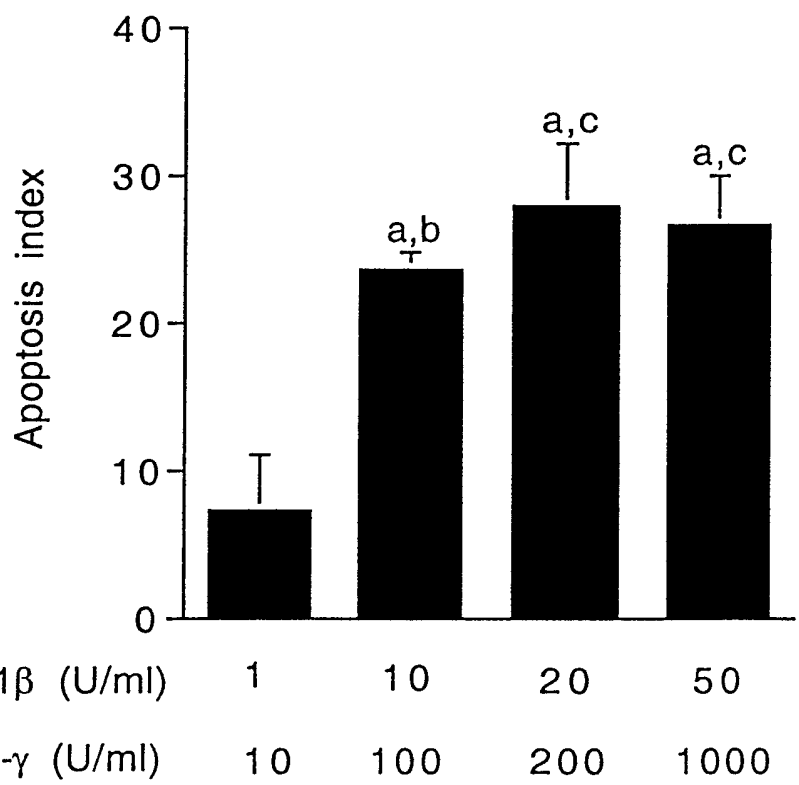

Fig. 1. Prevalence of apoptosis in beta cells exposed for 9 days to different concentrations of IL- $1 \beta$ and IFN- $\gamma$. Cell viability was determined with the DNA binding reagents HO 342 and $\mathrm{PI}$ and the apoptotic index calculated as described previously [94]. Apoptosis values in control beta cells were $6.5 \pm 1.5 \%$. ${ }^{\mathrm{a}} p<0.05$ vs controls (beta cells not exposed to cytokines); ${ }^{\mathrm{b}} p<0.05$ and ${ }^{\mathrm{c}} p<0.01$ vs IL- $1 \beta 1 \mathrm{U} / \mathrm{ml}+\mathrm{IFN}-\gamma 10 \mathrm{U} / \mathrm{ml}$; ANOVA. Data are means \pm SEM of 4 experiments.

When whole rat islets were exposed to IL- $1 \beta+$ IFN$\gamma+$ TNF- $\alpha$ there was a significant increase predominantly in necrosis ( $17 \%$ dead cells after $24 \mathrm{~h})$, whereas apoptosis was increased to a lesser extent $(5 \%$ dead cells after $24 \mathrm{~h}$; [99]). Both forms of cell death were abolished by concomitant exposure to an iNOS blocker [99], which also prevented cytokine-induced DNA loss in NMRI islets [100]. Whole islets isolated from $\mathrm{iNOS}^{-/-}$mice are much more resistant to IL$1 \beta+$ IFN- $\gamma+$ TNF- $\alpha$-induced cell death than wild type (wt) islet cells $(93 \%$ dead cells in the wt group vs $28 \%$ dead cells in the iNOS ${ }^{-/-}$mice after 9 days exposure to cytokines) [95]. These findings suggest that iNOS-mediated nitric oxide formation is more important for cytokine-induced cell death in whole rodent islets than in purified beta cells. This could be due to the disappearance of intercellular capillary spaces in whole islets kept in culture for more than $48 \mathrm{~h}$, leading to central ischaemia and allowing local accumulation of high amounts of nitric oxide [96]. However, it cannot be excluded that beta-cell FACS-purification, and the consequent loss of cellular contacts, modify the susceptibility of these cells to apoptosis.

Experiments with human pancreatic islets provide more uniform results. After 6 to 9 days of exposure of whole human islets and purified beta cells to IL$1 \beta+$ IFN- $\gamma$ or IL- $1 \beta+$ IFN- $\gamma+$ TNF- $\alpha$ there is induction of functional inhibition [91, 101, 102], DNA strand breaks $[103,104]$ and cell death by apoptosis, with a negligible necrotic component $[93,96,104]$. 
The induction of functional inhibition, DNA strandbreaks and apoptosis is independent of nitric oxide generation, since they cannot be prevented by iNOS blockers [96, 102-104]. Both human and rodent islets produce similar amounts of nitric oxide after exposure to cytokines but while the radical contributes to rat and mouse-islet cell death (see above), it seems less relevant for the demise of human beta cell. This difference between species has been discussed in detail elsewhere [7] and is probably due to the better capacity of human islets to scavenge oxygen free radicals [105] and to the higher content of heat shock protein 70 (hsp70) in these cells [105, 106]. Hsp70 has a direct anti-apoptotic role, by inhibiting protein aggregation, decreasing formation of oxygen free radicals and blocking effector caspases and it could also decrease necrosis by preventing cellular ATP depletion [107].

The experiments described above indicate that cytokines can directly induce beta-cell death. Two other possible mechanisms by which cytokines could contribute to beta-cell apoptosis in early Type I diabetes is by the up-regulation of Fas [7] and interaction with molecules generated during viral infections. Viral infections probably contribute to the pathogenesis of Type I diabetes [108]. Enteroviruses infect human beta cells in culture, inducing dysfunction and death [108, 109]. A common pathway for viral-induced cellular response in eukaryotic cells is through the cytosolic accumulation of double-stranded RNA (dsRNA; [110]. DsRNA, tested in the form of synthetic polyinosinic-polycytidylic acid, inhibits (pro)insulin biosynthesis in mouse islets [111] and with IL- $1 \beta$ and/or IFN- $\gamma$, leads to beta-cell death [97, 112] mostly by apoptosis [97]. While IL$1 \beta+$ dsRNA-induced apoptosis is nitric oxide-dependent, IFN- $\gamma+$ dsRNA leads to beta-cell death by a nitric oxide-independent mechanism [97]. The nature of this "nitric oxide-independent pathway" remains to be determined. In other cell types, dsRNA signals, at least in part, via activation of a double-stranded (ds) RNA-dependent protein kinase receptor (PKR). PKR was recently shown to be present and up-regulated by IL- $1 \beta$ in pancreatic beta cells [113]. Recent data suggest that islets isolated from mice with catalytically inactive PKR (PKR-/-) are protected against islet cell apoptosis but not against nitric-oxide mediated islet cell dysfunction and necrosis $[114,115]$. PKR could degrade $\mathrm{I} \varkappa \mathrm{B}$ and activate nuclear factor- $\varkappa \mathrm{B}(\mathrm{NF}-\varkappa \mathrm{B})$ by a specific binding of PKR to the $\mathrm{I} \varkappa \mathrm{B}$ kinase (IKK) beta subunit of the IKK complex, independent of PKR catalytic activity $[116,117]$. Further studies are required to determine the exact role of PKR in the process of dsRNA $+\mathrm{IL}-1 \beta$ or dsRNA + IFN- $\gamma$ induced beta-cell death by both apoptosis and necrosis. These observations indicate that viral products, in synergism with local cytokine production, could contribute to beta-cell apoptosis in early Type I diabetes.
In summary, there is now a consensus that cytokines are direct mediators of beta-cell death. This occurs by both apoptosis and necrosis, with apoptosis as the predominant form of cytokine-induced beta-cell death in human islets. The radical nitric oxide, produced by islet cells exposed to cytokines, has as more relevant role for the necrotic than for the apoptotic component.

The steps mediating cytokine signalling to the beta cells include: (1) cytokine binding and activation of specific receptors; (2) signal transduction mediated by cytosolic kinases and/or phosphatases; (3) mobilization of diverse transcription factors, such as NF$\varkappa \mathrm{B}$ and STAT- 1 which are kept inactive in the cytosol, or de novo synthesis of transcription factors, such as interferon regulatory factor 1 (IRF-1) and AP-1; (4) import of the activated or newly transcribed transcription factors into the nucleus, where they bind specific sites at the promoter region of responsive genes, up- or down-regulating gene transcription; (5) mRNA export to the cytosol, followed by translation into proteins. In some cases, cytokines exert their actions via phosphorylation and/or dephosphorylation of pre-existing proteins (steps 1 and 2), directly modifying their functions and by-passing steps 3 to 5 .

Cytokine receptors and signalling mechanisms in pancreatic beta cells. The IL-1 protein family consists of the two agonists IL- $1 \alpha$ and IL- $1 \beta$ and the IL- 1 receptor antagonist (IL-1Ra). The two agonists signal via the same receptor [118], whereas IL-1Ra does not induce signal transduction. There are two IL-1 receptors: IL-1 receptor type 1 and 2 (IL-1R1/2) and beta cells express both IL-1R1 and IL-1R2 [118]. The low affinity IL-1R1 is the signal-transducing receptor, whereas the high affinity IL-1R2 is a decoy receptor [118]. Upon binding of IL-1 to IL-1R1 conformational changes allow docking of an IL-1 receptor accessory protein (IL-1AcP) to the IL-1R1/IL-1 complex (Fig. 2) and binding of IL-1RAcP is crucial for IL-1 signalling. IL-1-induced signal transduction involves three major pathways, i.e. the activation of: nuclear factor $\varkappa \mathrm{B}(\mathrm{NF} \varkappa \mathrm{B})$; mitogen-activated protein kinases (MAPK); and protein kinase C (PKC). The IL-1R1 cytoplasmic domain contains putative GTPase activity and hydrolysis of GTP occurs very early after IL-1 $\mathrm{R} 1$ activation. Upon IL-1 binding the IL-1RI activated kinase (IRAK) is recruited to the IL-1/IL-1R1/ IL-1AcP complex by the adaptor protein MyD88, which is expressed in beta cells [119]. IRAK recruitment is essential for IL-1 induced signalling and it interacts with the TNF-receptor-associated factor-6 (TRAF6), which has been implicated in NF- $\varkappa \mathrm{B}$ activation via the NF- $\varkappa \mathrm{B}$ inducing kinase (NIK). Nuclear factor- $x \mathrm{~B}$ inducing kinase activates the inhibitory $\varkappa \mathrm{B}$ $(\mathrm{I} \varkappa \mathrm{B})$ kinase $(\mathrm{IKK})$ causing phosphorylation and degradation of $\mathrm{I} \varkappa \mathrm{B}$ and the release of $\mathrm{NF} \varkappa \mathrm{B}$, which then translocates to the nucleus and induces gene 


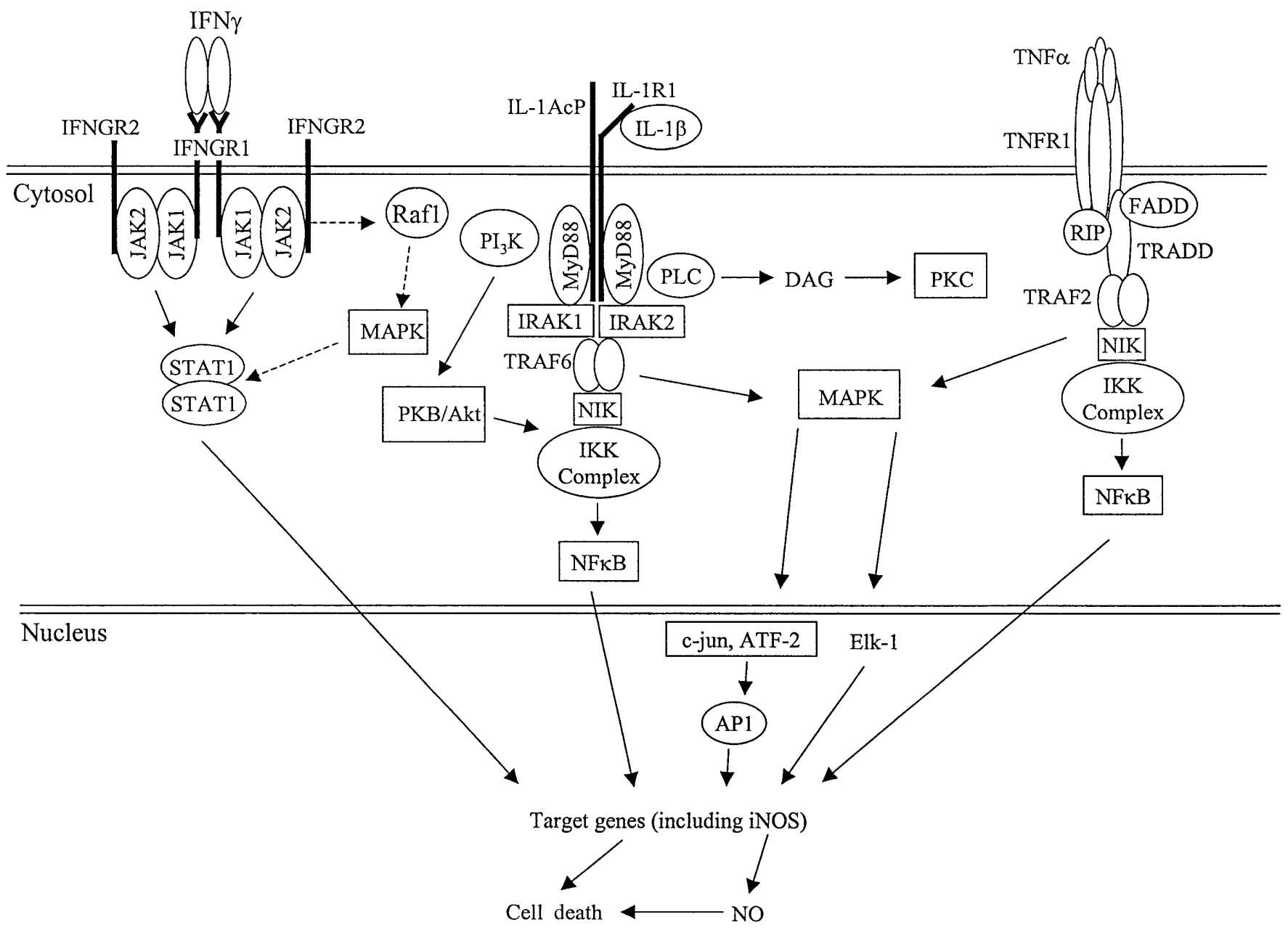

Fig. 2. Signalling mechanisms and cross-talk between IL-1 $\beta$, IFN $\gamma$ and TNF $\alpha$ receptors. IFN $\gamma$ signals mainly via the JAK/ STAT pathway. TNF $\alpha$ and IL- $1 \beta$ signalling converge on the NIK/IKK/NF $x$ B and MAPK pathways. IL-1 also signals via PI3 kinase-dependent PKB activation and via phospholipase $\mathrm{C}$ and diacylglycerol dependent PKC activation. NF $\varkappa \mathrm{B}$ is the main transcription factor for iNOS gene expression and probably for the expression of other key genes, still to be identified. AP-1 could be the prime transcriptional factor leading to MAPK dependent apoptosis. MAPKs provide cross-talk links between the signalling pathways of the three cytokines, allowing explanations for the observed synergistic activities of these cytokines on pancreatic beta-cell function and viability

transcription [120]. Phosphatidylinositol-3 kinase (PI3K) is also strongly activated and recruited to the IL-1 R1 after IL-1 binding [121] and inhibition of PI3K abrogates IL-1 induced signalling via NF $2 B$ and the activating transcription factor 1 (AP-1). $\mathrm{PI} 3 \mathrm{~K}$ could also regulate $\mathrm{PKC}$ and protein kinase $\mathrm{B}$ (PKB/Akt) activity [122].

Interferon- $\gamma($ IFN $\gamma$ ) signals via the IFN $\gamma$ receptor 1 (IFN $\gamma \mathrm{R} 1)$, which dimerizes and subsequently recruits two identical membrane associated accessory factor proteins (IFN $\gamma$ receptor 2, IFN $\gamma$ R2) (Fig. 2).
IFN $\gamma \mathrm{R} 1$ and IFN $\gamma \mathrm{R} 2$ are associated with the socalled Janus tyrosine kinases 1 and 2 (JAK1/2). When IFN $\gamma \mathrm{R} 1$ and 2 are brought together, JAK1 and 2 are activated by auto-phosphorylation and transphosphorylation. Phosphorylation of the IFN $\gamma \mathrm{R}$ allows docking of two signal transducers and activators of transcription 1 molecules (STAT1). After docking, STAT1 is activated through phosphorylation by JAK2. STAT1 then homodimerizes and translocates to the nucleus where it binds to gamma-activated sites in the regulatory regions of more than a hundred different genes [123]. STAT1 also activates the transcription factor IRF-1 and IRF-1 binds to interferon-stimulated response elements in many genes. STAT1 regulates caspase expression and thereby cellular response to pro-apoptotic stimuli [124]. The JAKS can also activate the extracellular signal-regulated kinase (ERK) MAPK, PI3 K and phospholipase $\mathrm{A}_{2}$ accounting for cross-talk with the IL-1 receptor signalling pathway [125].

The TNF 18-member superfamily, including lymphotoxin $(\mathrm{TNF} \beta)$, FasL and TRAIL [126] signals through the p60 and p80 TNF receptors. The p60 receptors are expressed ubiquitously, whereas expression of the p80 receptor is primarily found on immune and endothelial cells. The p60 and p80 recep- 


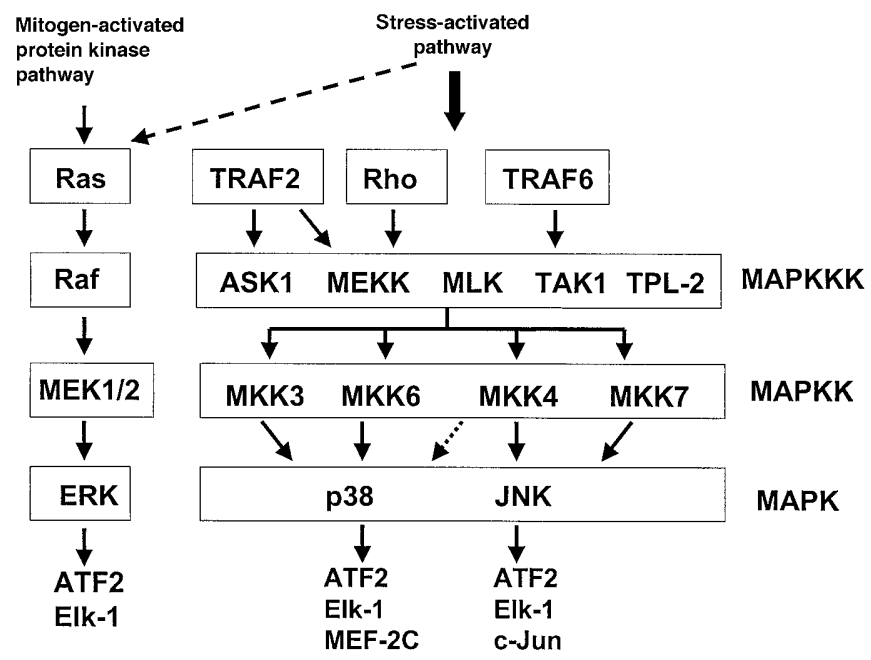

Fig.3. Schematic representation of stress-activated and mitogen-activated protein kinase pathways. Mitogens and cellular stresses operate via different but also partially overlapping early signalling events. This involves Ras as the main early activator of the classic mitogen-activated protein kinase pathway, while TRAF2/6 and Rho are early activators of the stress-activated pathway. Ras activation leads to signalling via Raf/ $\mathrm{MEK} / \mathrm{ERK}$, whereas both distinct and overlapping MAPK kinase kinase, MAPK kinase and MAPK operate in the stressactivated kinase cascade. $M E K, \mathrm{MAPK} / \mathrm{ERK}$ kinase

tors have similar extracellular but different intracellular domains. The p80 receptor lacks the so-called death domain found on the p60 receptor cytosolic portion, which is considered crucial for transmitting the death signal. The p60 receptor undergoes conformational change after ligand binding and then trimerizes. The death domain of the activated receptor cytoplasmic portion interacts with the TNF receptor associated death domain (TRADD), which in turn recruits the Fas-associated death domain (FADD) (Fig. 2). TRAF2 and the receptor interacting protein then binds to the p60/TRADD/FADD complex [127]. Following these immediate early events, phospholipases and sphingomyelinases are activated leading to generation of arachidonic acid and diacylglycerol as well as ceramide. Further, protein kinases such as NIK, PKC, c-jun N-terminal kinase (JNK), p38 and PKR are involved in TNF induced signalling [127]. Apoptosis mainly results from MAPK activation of caspase 3 or FADD mediated activation of caspase-8, in turn triggering the final effector caspases [126].

IL-1 and TNF signalling converges on the NIK$\mathrm{NF}$ B and MAPK pathways, whereas IFN signals mainly via the JAK/STAT pathway, which has crosstalk with the MAPK kinase cascade. The following section concentrates on the role of cytokine-mediated stress-activated and mitogen-activated protein kinases in beta-cell apoptosis.

Mitogen-activated and stress-activated protein kinases. Cellular decision-making on whether extracellular stimuli result in cell division, differentiation or death depends on the co-operation of many signal transduction pathways of which the mitogen-activated and stress-activated protein kinases are important regulators. The dominant members of the MAPK family are the ERK, which is mainly activated by mitogens but also by cellular stressors, and the stress-activated protein kinases p38 and JNK, which are activated by cytokines, changes in extracellular osmolarity or irradiation. All three MAPK's are activated by threonine and/or tyrosine phosphorylation by upstream kinases (Fig. 3). The active MAPKs in turn phosphorylate serine and threonine residues in substrate proteins including downstream protein kinases and transcription factors. The MAPK pathways are true cascades that enable amplification but also constitute distinct cellular check-points that provide specificity of the intracellular signal in response to pleiotropic stimuli at each level (Fig. 3) [128]. The signalling gateways from the interleukin-1 receptor complex occur mainly at the IRAK tyrosine kinase activation of Ras and Rho as well as TRAF-6, whereas the TNF gateway is mainly TRAF-2 (Fig. 2). IFN- $\gamma$ signalling cross-talks with the MAPK cascade by JAK activation of Raf [128, 129].

Recent evidence strongly suggests that MAPKs are crucial signalling elements in cytokine-mediated effects in beta cells. It seems that the MAPK response is differentiated into cytokine-mediated nitric oxide-dependent and independent events.

MAPK signalling of cytokine-mediated nitric oxide dependent events. Cytokine-activation of the iNOS gene promoter in beta cells is mainly dependent upon binding of the transcription factor NFxB. p38 MAPK could activate NF- $x \mathrm{~B}$ and also potentiate $\mathrm{NF}-\varkappa \mathrm{B}$ binding via activation of the transcription factors activating transcription factor 2 (ATF-2) and AP-1 [130]. We therefore investigated if cytokines activate the p38 and ERK signalling pathways in pancreatic islets. IL- $1 \beta$ stimulated ERK-1/2 and p38/ MAPK in both isolated pancreatic rat islets and in RIN cells within minutes and this response was surprisingly sustained for up to 6 to $12 \mathrm{~h}$ [131]. Combined inhibition of the p38 and ERK pathways completely blocked IL-1-induced iNOS expression and nitric oxide synthesis but only partially prevented IL-1 induced inhibition of islet insulin release [131]. A non-cytokine stimulus of MAPK pathways by hyperosmolarity did not, however, result in nitric oxide production suggesting that p38 and ERK are necessary but not sufficient for IL-1 induced iNOS expression. Further, TNF $\alpha$ and IFN $\gamma$, known to potentiate most IL-induced beta-cell effects also potentiated IL-1 beta-stimulated beta-cell MAPK activity [132]. These data suggest that the ERK and p38 pathways are important regulators of cytokine-mediated betacell nitric oxide production. 
MAPK signalling of nitric oxide independent events. To investigate the role of the p38 and ERK pathways in cytokine-induced beta-cell apoptosis, we studied the effect of inhibitors of these pathways on IL$1+$ IFN- $\gamma$-induced apoptosis in primary FACS purified beta cells [133]. Although the inhibitors reduced cytokine-induced beta-cell nitric oxide production, the p38 inhibitor failed to prevent apoptosis, whereas the ERK inhibitor moderately reduced cytokine-induced apoptosis.

Apart from activating the ERK and p38 pathway, IL-1 also activates the JNK pathway [131, 134-136]. Taking advantage of the inhibitory properties of the JNK scaffold protein islet brain 1 (IB-1) or the JNK binding domain (JBD) of this protein, it was possible to show either by overexpressing IB-1 or JBD, or by using cell permeable JBD fused to the HIV Tat protein, that JNK inhibition prevents IL-1 induced apoptosis in several transformed beta-cell lines without blocking nitric oxide production [135, 137]. Of interest, IL-1 reduced beta-cell IB-1 expression [136] increasing the susceptibility of the beta cells to JNK proapoptotic signalling.

These data indicate that MAPKs are central for the signalling of nitric oxide-dependent and nitric oxide-independent effects of cytokines in beta cells. The ERK/p38 pathways are necessary but not sufficient for iNOS expression, whereas the JNK pathway is important for apoptosis induction, at least in transformed beta cells. The protective effect of JNK inhibition against cytokine-induced apoptosis should be tested in primary beta cells, which could have very different MAPK requirements than rapidly dividing and de-differentiated cells.

The MAPK pathways could also provide signalling links to other cytokine-mediated events in pancreatic beta cells. Thus, the p38 MAPK was found to be responsible for signalling of glucose-mediated potentiation of IL-1 induced nitric oxide production and inhibition of insulin release [138]. Cytokine-induced nitric oxide production could be involved in a positive feedback of the MAPK signal [139] providing an explanation for the protracted MAPK activation in cytokine-exposed beta cells [131] and a potential signalling mechanism for nitric oxide induced apoptosis. Since a sustained increase in the cytosolic free calcium concentration has been associated with cytokineinduced apoptosis, and inhibition of high voltage dependent calcium channels protects against cytokineinduced beta-cell apoptosis [140], it is of interest that inhibition of voltage dependent calcium channels reduced IL-1-stimulated JNK and p38 activity [141].

Activation of cytosolic MAPKs modifies the activity/expression of transcription factors, leading to changes in nuclear gene transcription (Fig.3).

Transcription factors, gene patterns and beta-cell death. The induction of significant beta-cell apoptosis after exposure of purified human, mouse or rat cells to cytokines requires 3 to 9 days [95, 104, 133]. This suggests that de novo gene expression is required for cytokine-induced beta-cell death. Years of research aiming to identify the gene(s) responsible for this process, using the "candidate gene approach" and differential display by reverse transcription-polymerase chain reaction, failed to provide a unifying explanation for the phenomenon [7]. This suggests the possibility that apoptosis in primary beta cells - a complex biological phenomenon - is not induced by modifications in the expression of one or two genes, but is instead caused by parallel and/or sequential modifications in a large number of genes [7]. At present it is possible to evaluate complex patterns of gene or protein expression by high-density microarrays or proteomics respectively [142-144]. High-density oligonucleotide arrays have already been utilized to determine IL- $1 \beta$ or IL- $1 \beta+$ IFN- $\gamma$-induced gene expression in primary rat beta cells $[145,146]$ and IL-1-induced gene expression in transformed RINm5F cells [147]. Proteomic analysis has been done on neonatal rat islets exposed to IL- $1 \beta$ alone $[148,149]$, allowing the identification of many interesting proteins regulated by IL- $1 \beta$ [149] or changed as a consequence of IL- $1 \beta$-induced nitric oxide formation [148]. Proteomics represent an important supplement to gene arrays since gene transcription does not inevitably result in translation and because proteomics also detect posttranslatory protein modifications.

An overview on cytokine-induced changes in primary beta-cell gene expression with potential relevance for cell death is given in Table 5 (based on a microarray analysis in primary beta-cells) [146]. If we accept the concept that beta-cell apoptosis is caused by massive changes in gene expression, we should then look beyond individual genes and focus instead on the transcription factors that regulate "gene modules" involved in beta-cell apoptosis (Fig.4). From the transcription factors depicted in Figure 4, two have a high probability of regulating groups of genes contributing to beta-cell death: NF- $x$ B and STAT-1, mediating the signal transduction of IL- $1 \beta$ and IFN- $\gamma$ respectively.

Under basal conditions, $\mathrm{NF}-\varkappa \mathrm{B}$ remains inactive in the cytoplasm, bound to the inhibitory molecule $\mathrm{I} x \mathrm{~B}$. Following stimuli by cytokines, viral or bacterial products, $\mathrm{I} \varkappa \mathrm{B}$ is phosphorylated and degraded in the proteasome, freeing $\mathrm{NF}-\varkappa \mathrm{B}$ for nuclear translocation [120]. In the nucleus NF- $x \mathrm{~B}$ modifies the transcription of genes containing NF- $x \mathrm{~B}$-binding sites in their promoter regions [150] and several of these genes have a key role in inflammation and could affect the process of cell death $[151,152]$. Beta-cell exposure to IL- $1 \beta$ also causes NF- $x \mathrm{~B}$ translocation to the nucleus [153], and studies using transient transfections with promoter-luciferase constructs have shown that 
Table 5. Cytokine-induced changes in beta-cell gene expression with a potential role in the process of beta-cell death

\begin{tabular}{|c|c|}
\hline Contributing to beta-cell death & Favouring beta-cell survival \\
\hline Increased cytokine signalling & $\begin{array}{l}\text { Negative feedback on cyto- } \\
\text { kinesignalling }\end{array}$ \\
\hline NF- $\varkappa B$ p105 (I) & $\mathrm{I} \varkappa \mathrm{B} \alpha(\mathrm{I})$ \\
\hline JAK-2 (I) & SOCS (I) \\
\hline ERK-3 (I) & $\begin{array}{l}\text { CL100 tyrosine protein phos- } \\
\text { phatase (I) }\end{array}$ \\
\hline $\begin{array}{l}\text { P38 MAPK (I) } \\
\text { MAPK phosphatase (D) }\end{array}$ & A20 (I) \\
\hline $\begin{array}{l}\text { Decreasing ATP and cAMP } \\
\text { formation } \\
\text { GLP-1 receptor (D) } \\
\text { GIP receptor (D) } \\
\text { GLUT2 (D) } \\
\text { Glucokinase (D) } \\
\text { Cytochrome b.5 reductase (D) }\end{array}$ & $\begin{array}{l}\text { Increasing ATP and cAMP } \\
\text { formation } \\
\text { Glucagon receptor (I) } \\
\text { GLUT1 (I) } \\
\text { ANT-1 (I) }\end{array}$ \\
\hline $\begin{array}{l}\text { Decrease in defence/repair } \\
\text { Glutathione peroxidase (D) } \\
\text { Gas-6 growth arrest specific (D) }\end{array}$ & $\begin{array}{l}\text { Increase in defence/repair } \\
\text { MnSOD (I) } \\
\text { Metallothionein (I) }\end{array}$ \\
\hline $\begin{array}{l}\text { The nitricoxide formation } \\
\text { module } \\
\text { iNOS (I) } \\
\text { Argininosuccinate synthetase (I) } \\
\text { Arginase (D) }\end{array}$ & $\begin{array}{l}\text { Hsp } 27(\mathrm{I}) \\
\text { Hsp } 70(\mathrm{I}) \\
\text { MGMT (I) } \\
\text { Gas } 5 \text { growth arrest homolog } \\
\text { (I) }\end{array}$ \\
\hline $\begin{array}{l}\text { Apoptosis-related genes } \\
\text { Death protein-5 (I) } \\
\text { Fas (I) } \\
\text { Caspase-1 (I) } \\
\text { c-myc (I) } \\
\text { GADD 153/CHOP (I) } \\
\text { Bcl-2 (D) } \\
\text { Bax-omega (D) }\end{array}$ & $\begin{array}{l}\text { Serine protease inhibitor-3 (I) } \\
\text { Osteoprotegerin (I) }\end{array}$ \\
\hline
\end{tabular}

${ }^{a}$ mRNA expression modified at $72 \mathrm{~h}$ [174]

Gene expression was modified by IL- $1 \beta$ and/or IFN- $\gamma$ after an exposure period of 6-24 h (preceding actual beta-cell apoptosis, which is detectable after 3-6 days). References and discussion on most individual genes is provided in [146] and [7]. SOCS and A20 are described in [160, 179]. I increased; D, decreased; ANT, adenine nucleotide translocator; GADD, growth arrest and DNA damage inducible; MGMT, O-6 methylguanine-DNA methyltransferase; SOCS, suppressor of cytokine signalling; CHOP, CIEBP homologous protein

$\mathrm{NF}-x \mathrm{~B}$ is required for IL- $1 \beta$-induced expression of mRNAs for iNOS [154], Mn superoxide dismutase (MnSOD) [155] and Fas [156]. This, and the observation that nearly 20 genes induced by cytokines in beta cells - several of them with putative pro-apoptotic role - are potentially NF- $\varkappa$ B-regulated [146], suggest a role for the transcription factor in the process of beta-cell death. This hypothesis was tested by infecting purified rat beta cells with a recombinant adenovirus containing a non-degradable mutant form of $\mathrm{I} \varkappa \mathrm{B}$, which prevents $\mathrm{NF}-\varkappa \mathrm{B}$ nuclear translocation in these cells. This NF- $x \mathrm{~B}$ blocker prevented cytokineinduced iNOS and Fas expression and significantly improved beta-cell survival, mostly through the inhibition of apoptosis [157]. Similar results were ob- tained in whole human islets, where blocking of NF$\varkappa \mathrm{B}$ activation decreased IL- $\beta$-induced caspase 3 activity, used in the study as an indicator of apoptosis [158]. However, the authors did not characterize the nature of the islet cells undergoing apoptosis and it is not clear whether they are indeed beta cells. Moreover, it is surprising that they observed human-islet cell death with IL-1 $\beta$ alone [158] - most studies, using well characterized human islet preparations, have shown that these cells are only killed by combinations of 2-3 cytokines [96, 103, 104]. In line with the observations suggesting a pro-apoptotic role for $\mathrm{NF}-x \mathrm{~B}$, expression of a dominant negative inhibitor of $\mathrm{NF} \varkappa \mathrm{B}$ in insulin-producing MIN6 cells provides a partial protection against IL- $1 \beta+\mathrm{IFN} \gamma+\mathrm{TNF} \alpha$-induced apoptosis [159]. Of note, NF- $x \mathrm{~B}$ also regulates expression of genes which probably oppose beta-cell death, namely MnSOD [155], A20 [160] and $\mathrm{I} x \mathrm{~B} \alpha$ (which could act as a negative feedback for the NF$x \mathrm{~B}$ activation) [146]. Cytokine-exposed beta cells express several other genes with putative roles in repair of DNA and defence against cellular stress (Table 5) but it is not clear if these genes are also activated by $\mathrm{NF}-\varkappa \mathrm{B}$. As suggested by the blocking experiments, the predominant effect of NF- $\varkappa \mathrm{B}$-dependent genes is to contribute to beta-cell apoptosis. The nature of these NF- $x \mathrm{~B}$-controlled pro-apoptotic genes has yet to be determined but probably Fas, iNOS and $c-m y c$ contribute to cell death (Table 5, Fig.4). These are certainly not the only genes involved, since firstly, Fas up-regulation cannot explain the observed in vitro cytokine-induced cell death, because no Fas ligand is present in the culture medium and rat beta cells do not express this ligand; and secondly, beta cells isolated from iNOS-/- mice die by apoptosis after exposure to cytokines. At present we are doing a new microarray analysis of beta cells exposed to cytokines with or without the concomitant presence of the non-degradable mutant form of $\mathrm{I} \varkappa \mathrm{B}$. Hopefully, these experiments will show the NF- $x \mathrm{~B}$-regulated "gene modules" involved in beta-cell death.

As discussed above, IL- $1 \beta$ alone does not induce death in purified human, rat or mouse beta cells. However, when IL- $1 \beta$ is combined with IFN- $\gamma$, with or without the presence of TNF- $\alpha$, a large proportion of these cells undergo apoptosis [94-96, 104, 133]. This indicates that the signal transduction mediated by IFN- $\gamma$ is required for beta-cell apoptosis. IFN- $\gamma$ binds to cell surface receptors and activate the tyrosine kinases JAK1 and JAK2 [161]. IL- $\beta$ up-regulates JAK2 expression in beta cells [146], probably potentiating IFN- $\gamma$ signalling. These kinases phosphorylate STAT1, which migrates to the nucleus and binds to $\gamma$-activated sites of diverse genes [161]. One of the genes activated by STAT1 is interferon-regulatory factor-1 (IRF-1), a transcription factor which regulates several IFN- $\gamma$-dependent genes. IRF-1 is involved in iNOS regulation in macrophages [162] 


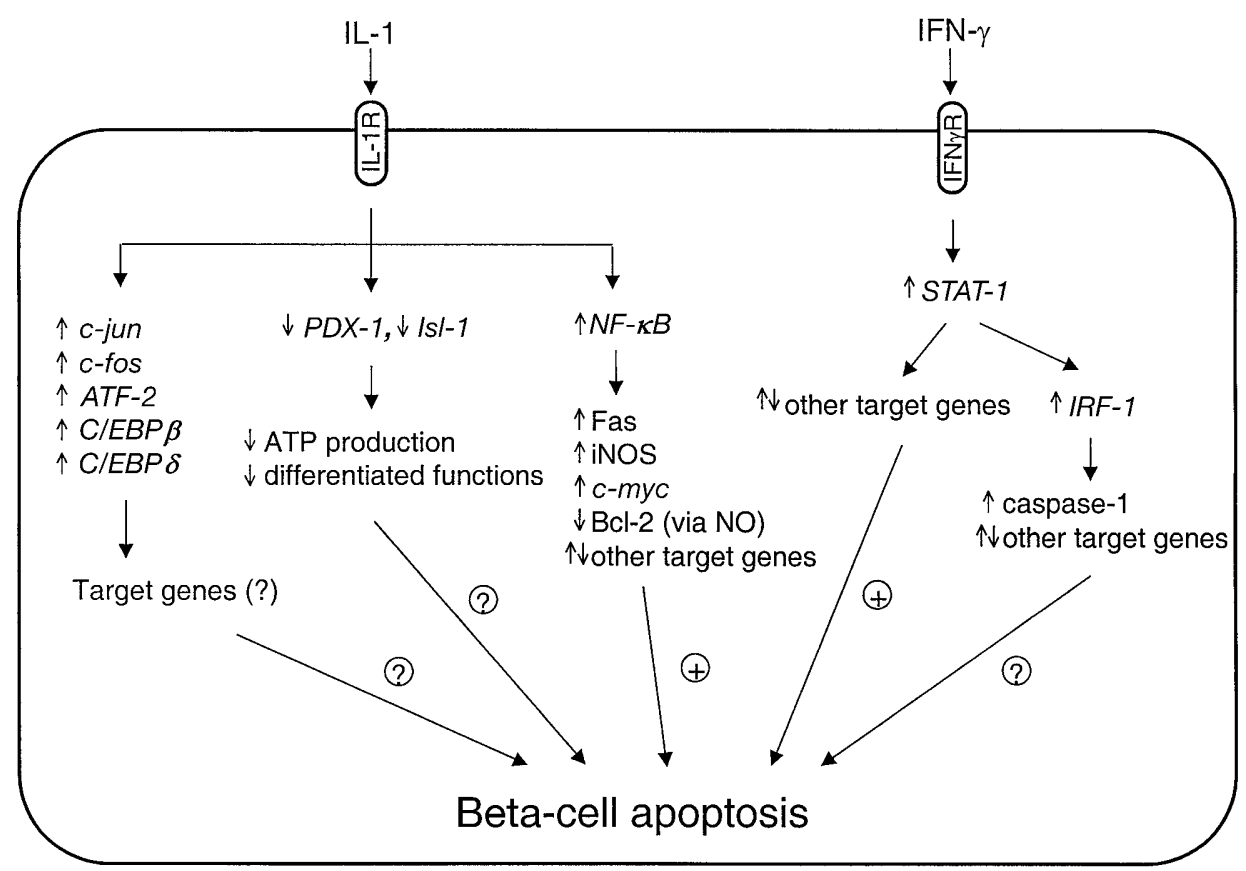

Fig.4. Transcription factors (italics) potentially involved in the regulation of genes and cellular processes with a putative role in beta-cell apoptosis

and in triggering apoptosis in $\mathrm{T}$ lymphocytes [163]. Thus, IRF-1 seemed to be a logical mediator for the contribution of IFN- $\gamma$ to beta-cell death. This hypothesis was proven incorrect, when it was shown that beta cells obtained from IRF-1-/- mice are as susceptible to cytokine-induced apoptosis as beta cells obtained from wt mice [94]. Islets isolated from IRF$1-/-$ and allografted into wt mice are more susceptible to destruction than islets isolated from wt mice, suggesting that this transcription factor could actually regulate putative "protective" genes [81]. If we exclude IRF-1, the main alternative candidate is STAT1. STAT1 activation is the main mediator of IFN- $\gamma$ effects on iNOS expression in insulin producing cells [154] and expression of this transcription factor, together with IRF-1, is up-regulated in islet cells from diabetes-prone NOD mice [164]. Moreover, STAT-1 is critical for ischaemia-induced apoptosis in cardiomyocytes [124] but whether this transcription factor has a similar role in beta-cell apoptosis is not known.

Besides leading to beta-cell apoptosis via NF- $\varkappa \mathrm{B}$ and STAT1 activation, cytokines could also affect beta-cell survival by decreasing its capacity to metabolize glucose and produce ATP; decreasing cAMP formation; and affecting the handling of $\mathrm{Ca} 2+$ (genes potentially related to these three effects are described in Table 5 and in [146]). At least under in vitro conditions cAMP formation is required for betacell viability [165] and a decrease in GLP-1 and gas- tric inhibitory peptide (GIP) receptors induced by cytokines [146] will probably contribute to reduced intracellular cAMP content in vivo. A decrease in ATP, mediated by direct inhibitory effects of nitric oxide on beta-cell mitochondria [166] and by decreased expression of GLUT2 and glucokinase [146] could contribute to beta-cell necrosis [7]. These phenomena are probably part of a general process of cytokine-induced beta-cell "de-differentiation", with impairment of some of the most differentiated functions of beta cells, such as the preferential mitochondrial metabolism of glucose and the (bio)synthesis and release of insulin $[167,168]$. This is paralleled by the activation of proteins related to cell survival, such as heat shock proteins and antioxidant enzymes $[146,153]$. This "de-differentiation" is probably associated to cytokine-induced up-regulation of the transcription factor $c-m y c$ [146] and down-regulation of PDX-1 [169] and Isl-1 [146] (Fig. 4). Increased c-myc expression has been associated with beta-cell growth, de-differentiation and apoptosis, after partial pancreatectomy [170] and during transgenic c-myc expression in beta cells [171]. Since beta-cell growth is directly inhibited by cytokines [168], probably from a decreased expression of growth hormone and prolactin receptors and of cyclins [146], the pro-apoptotic effect of $c-m y c$ will preponderate. PDX-1 is a crucial gene for beta-cell development and for the maintenance of its differentiated phenotype [172]. The decreased expression of PDX-1, together with the inhibition of Isl-1 expression, could contribute to the observed decreased expression of insulin, GLUT2 and glucokinase mRNAs. While IL- $1 \beta$ alone induces inhibition of PDX-1 and Isl-1 and up-regulation of $c-m y c$, leading to severe inhibition of beta-cell function, it does not trigger beta-cell apoptosis (apoptosis is 
only present when IL- $1 \beta$ is combined with other cytokines). This suggests that beta-cell "de-differentiation", by itself, is not sufficient to cause apoptosis but it could synergise with the signal-transduction of NF- $x$ B, AP-1 and STAT-1 to trigger beta-cell death. In this context, it is conceivable that the special characteristics of beta cells - its low proliferative capacity, high dependence on mitochondrial function and low capacity to scavenge oxygen free radicals - makes them especially sensitive to dead signals. While beta cell maturation increases its sensitivity to cytokinemediated cell death $[135,173]$, IL- $1 \beta$-induced betacell "de-differentiation" (together with induction of hsp70 and free radical scavengers) decreases its susceptibility to necrosis induced by alloxan or streptozotocin [169].

In a microarray analysis carried out at the early stages of the apoptotic process (after 6 or $24 \mathrm{~h}$ of cytokine exposure), we did not observe changes of several "classic" pro-apoptotic and anti-apoptotic transcripts, such as Bcl-2, Bcl-x and Bad in primary beta cells [146]. Previous observations that cytokines inhibit Bcl-2 expression in both rat beta cells [174] and human islets [175] were obtained at later periods, and could be a consequence rather than the cause of apoptosis. We suggest that transcriptional regulation of genes from the $\mathrm{Bcl}-2$ family is not the main cause of cytokine-induced beta-cell death. Beta-cell apoptosis depends instead on the parallel and/or sequential up-regulation and down-regulation of a large number of genes combined with modifications on protein translation and activation [146]. A more detailed characterization of the gene groups regulated by NF- $x \mathrm{~B}, \mathrm{AP}-1$, STAT1 and the additional transcription factors described in Figure 4 might allow us to understand why beta cells eventually decide to start the process of apoptosis. This knowledge will open the door for "targeted" approaches to preserve beta-cell life and function in the pre-diabetic period.

\section{Models for immune-mediated nitric oxide dependent and independent beta-cell apoptotic pathways}

Based on the evidence reviewed above, we would like to propose two main effector pathways by which the beta cells succumb to cytokine-mediated destruction. The first (Fig.5) is a pathway dependent upon nitric oxide and therefore, for the reasons discussed above, probably mainly involved in cytokine-mediated rodent beta-cell destruction. In this model, nitric oxide mediated inhibition of aconitase (causing reduction in ATP generation) and DNA strand-breaks (causing activation of poly(ADP)ribose polymerase and $\mathrm{NAD}+$ depletion), leads to beta-cell necrosis. Nitric oxide-mediated signalling via guanylcyclase and PKG or via potentiation of MAPK, could lead to acti-

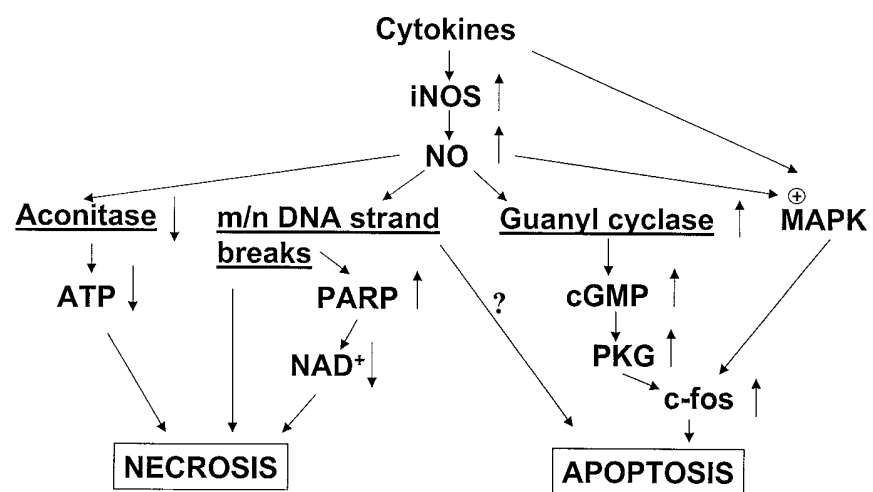

Fig. 5. Model for nitric oxide mediated beta-cell destructive pathways. Nitric oxide could elicit beta-cell necrosis via the inhibition of aconitase, DNA strand-breaks and/or NAD depletion secondary to DNA repair. Beta-cell apoptosis can be caused by nitric oxide activation of guanyl cyclase and protein kinase $\mathrm{G}$ as well as potentiation of MAPK

vation of c-fos, an important transcription factor in apoptosis induction [176, 177].

A simplified model for nitric oxide independent beta-cell destruction pathways is suggested (Fig. 6). The scheme implies that converging signalling from the IFN $\gamma$, IL- 1 and TNF $\alpha$ receptors towards MAPK activation, combined with IL-1 mediated activation of caspase-1 (interleukin-1 converting enzyme, ICE) and other genes still to be determined, leads to effector caspase activation and apoptosis. Similarly, TNF signalling via the FADD/MORT pathway could activate caspase-8, also resulting in apoptosis. It is likely that mitochondrial permeability transition pores are activated probably by the FADD/MORT pathway, leading to the release of cytochrome $\mathrm{c}$, and activation of caspase-9. This is followed by the liberation of calcium, a reduction in ATP generation and GSH as well as a generation of reactive oxygen species. Calcium could further participate in the apoptotic response, whereas the latter factors mainly contribute to necrosis. Some of these steps are blocked by the anti-apoptotic protein Bcl-2 [99, 178].

\section{Future directions for research in the field}

The understanding of the process of beta-cell apoptosis has gained a major impulse in recent years. However, as delineated in this review, our understanding is still fragmentary. Most of the available knowledge on the processes of apoptosis was gained in tumoural cells and it is conceivable that some of the mechanisms leading to cell death in fast dividing cells are of marginal relevance for primary and poorly dividing beta-cells. Several issues deserve further investigation. Among them: (i) The role of $\mathrm{Ca}^{+}$and of the factors regulating cytosolic and endoplasmic reticulum $\mathrm{Ca}^{+}$concentration on beta-cell apoptosis and 


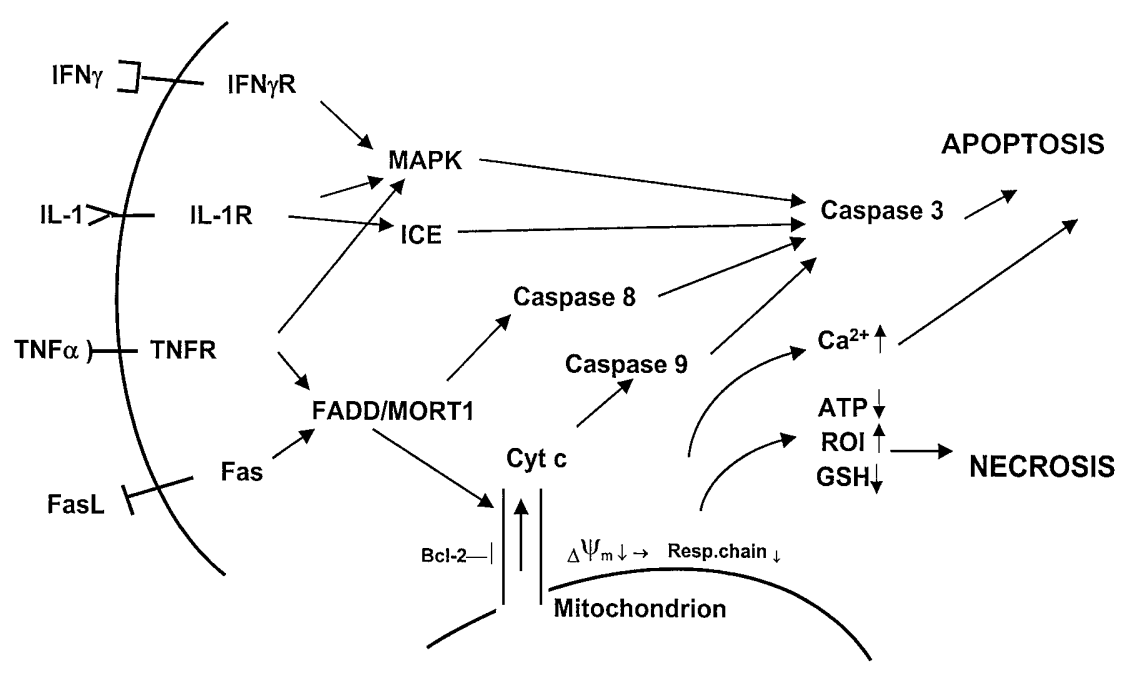

Fig. 6. Model for nitric oxide independent beta-cell destructive pathways. IFN $\gamma$, IL- 1 and TNF $\alpha$ signalling converges on MAPK, in particular JNK, which probably activates apoptosis via modification of gene expression and activation of effector caspases. The TNF receptor 1 death domain TRADD (Fig. 2) could also elicit apoptosis via interaction with the Fas associated death domain protein (FADD), also known as mediator of receptor-induced toxicity-1 (MORT-1). FADD causes both mitochondrial outer membrane transition pore, leading to release of cytochrome-c and caspase activation and the liberation of calcium that can also signal apoptosis. Further decrease in ATP generation, increased formation of reactive oxygen intermediates (ROI) and decrease of the reducing potential can lead to necrosis instead

necrosis; (ii) The cross-talk between IFN- $\gamma$ and IL- $1 \beta$ / TNF- $\alpha$ and how this cross-talk regulates gene expression and beta-cell apoptosis; (iii) The role of phosphatases, SOCS, IB-1 and JBD in the down-regulation of the pro-apoptotic signals delivered by cytokines; (iv) The nature of the transcription factors activated by MAPKs in beta cells; (v) A better understanding of the role for nitric oxide, and nitric oxide-dependent genes and proteins, in the process of beta-cell necrosis and apoptosis; (vi) The role of different members of the Bcl-2 family and of mitochondria for beta-cell death; (vii) A clearer understanding of the observed differences between cytokine-induced human and rodent beta-cell death - which will require the development of better techniques for reliable purification of human beta cells; and (viii) additional microarray and proteomic studies of the gene and protein "modules" participating in beta-cell apoptosis.

In "A Choice of Murder" [180], Peter Vansittart describes the life of Timoleon, the leading citizen of Syracuse in late 4 th century B.C. Forced to select between submission to one of the ascending empires of the period - Macedonia, Parthia or Persia - he choose instead to remain faithful to the end to the Greek ideal of a free City State. In this case, "The Choice of Death" provided an accurate picture of the deceased. It could be that unveiling the process of beta-cell death in Type I diabetes will allow not only a clearer understanding of the pathogenesis of the disease, but will also provide important insights into the basic characteristics of a beta cell. Indeed, we believe that the highly differentiated and sophisticated beta cell dies by apoptosis in early Type I diabetes at least in part because it is a highly differentiated and sophisticated cell.

Note added in proof: Recent evidence suggests that nitric oxide contributes to apoptosis in insulin-producing MIN6 cells by activating the endoplasmic reticulum stress pathway and increasing expression of GADD 153/CHOP [181]. Expression of GADD 153/ CHOP is up-regulated by IL- $1 \beta+$ IFN- $\gamma$ in primary beta cells [146], and this effect is prevented by iNOS inhibitors (Cardozo and Eizirik, unpublished data).

Acknowledgements. We are grateful to L. Brandt-Møller and R. Leeman for their secretarial and technical assistance. Work by the authors was supported by the Juvenile Diabetes Foundation International, the Flemmish Research Foundation (FWO), the Danish Research Council, the Danish Diabetes Association and Novo Nordisk.

\section{References}

1. Eizirik DL, Hoorens A (1999) $\beta$-cell dysfunction and death. In: Bittar EE, Howel SL (eds) Advances in Molecular and Cell Biology - The Biology of the Pancreatic $\beta$ Cell, Vol. 29. Jai Press, Stamford, pp 47-73

2. Mauricio D, Mandrup-Poulsen T (1998) Apoptosis and the pathogenesis of IDDM: a question of life and death. Diabetes 47: 1537-1543

3. Nicholson DW (2000) From bench to clinic with apoptosis-based therapeutic agents. Nature 407: 810-816

4. Bonner-Weir S (2000) Perspective: Postnatal pancreatic beta cell growth. Endocrinology 141: 1926-1929

5. Trudeau JD, Dutz JP, Arany E, Hill DJ, Fieldus WE, Finegood DT (2000) Neonatal beta-cell apoptosis: a trigger for autoimmune diabetes? Diabetes 49: 1-7 
6. Cerasi E, Kaiser N, Leibowitz G (2000) Type 2 diabetes and beta cell apoptosis. Diabetes Metab 26 [Suppl 3]: $13-16$

7. Eizirik DL, Darville MI (2001) $\beta$-cell apoptosis and defense mechanisms: lessons from type 1 diabetes. Diabetes 50 [Suppl 1]: S64-S69

8. Mandrup-Poulsen T (2001) $\beta$-cell apoptosis: stimuli and signaling. Diabetes 50 [Suppl 1]: S58-S63

9. Saraste A, Pulkki K (2000) Morphologic and biochemical hallmarks of apoptosis. Cardiovasc Res 45: 528-537

10. Savill J, Fadok V (2000) Corpse clearance defines the meaning of cell death. Nature 407: 784-788

11. Kurrer MO, Pakala SV, Hanson HL, Katz JD (1997) $\beta$-cell apoptosis in T cell-mediated autoimmune diabetes. Proc Natl Acad Sci U S A 94: 213-218

12. Augstein P, Elefanty AG, Allison J, Harrison LC (1998) Apoptosis and beta-cell destruction in pancreatic islets of NOD mice with spontaneous and cyclophosphamide-accelerated diabetes. Diabetologia 41: 1381-1388

13. O'Brien BA, Harmon BV, Cameron DP, Allan DJ (1997) Apoptosis is the mode of $\beta$-cell death responsible for the development of IDDM in the nonobese diabetic (NOD) mouse. Diabetes 46: 750-757

14. Augstein P, Stephens LA, Allison J et al. (1998) Beta-cell apoptosis in an accelerated model of autoimmune diabetes. Mol Med 4: 495-501

15. Kim YH, Kim S, Kim KA et al. (1999) Apoptosis of pancreatic $\beta$-cells detected in accelerated diabetes of NOD mice: no role of Fas-Fas ligand interaction in autoimmune diabetes. Eur J Immunol 29: 455-465

16. O'Brien BA, Harmon BV, Cameron DP, Allan DJ (1996) Beta-cell apoptosis is responsible for the development of IDDM in the multiple low-dose streptozotocin model. J Pathol 178: 176-181

17. Yamaoka T, Yano M, Idehara C et al. (1999) Apoptosis and remodelling of beta cells by paracrine interferon- $\gamma$ without insulitis in transgenic mice. Diabetologia 42: 566-573

18. Mandrup-Poulsen T (1996) The role of interleukin-1 in the pathogenesis of IDDM. Diabetologia 39: 1005-1029

19. Lally FJ, Ratcliff H, Bone AJ (2001) Apoptosis and disease progression in the spontaneously diabetic $\mathrm{BB} / \mathrm{S}$ rat. Diabetologia 44: 320-324

20. Stassi G, De Maria R, Trucco G et al. (1997) Nitric oxide primes pancreatic beta cells for Fas-mediated destruction in insulin-dependent diabetes mellitus. J Exp Med 186: 1193-1200

21. Moriwaki M, Itoh N, Miyagawa J et al. (1999) Fas and Fas ligand expression in inflamed islets in pancreas sections of patients with recent-onset Type I diabetes mellitus. Diabetologia 42: 1332-1340

22. Kreuwel HT, Sherman LA (2001) The role of Fas-FasL in $\mathrm{CD}^{+}$T-cell-mediated insulin-dependent diabetes mellitus (IDDM). J Clin Immunol 21: 15-18

23. Wong FS, Dittel BN, Janeway CA Jr (1999) Transgenes and knockout mutations in animal models of type 1 diabetes and multiple sclerosis. Immunol Rev 169: 93-104

24. Suri A, Katz JD (1999) Dissecting the role of CD4 ${ }^{+}$T cells in autoimmune diabetes through the use of TCR transgenic mice. Immunol Rev 169: 55-65

25. Peterson JD, Pike B, McDuffie M, Haskins K (1994) Isletspecific T cell clones transfer diabetes to nonobese diabetic (NOD) F1 mice. J Immunol 153: 2800-2806

26. Wang Y, Pontesilli O, Gill RG, La Rosa FG, Lafferty KJ (1991) The role of $\mathrm{CD}^{+}$and $\mathrm{CD}^{+} \mathrm{T}$ cells in the destruction of islet grafts by spontaneously diabetic mice. Proc Natl Acad Sci U S A 88: 527-531
27. Graser RT, DiLorenzo TP, Wang F et al. (2000) Identification of a CD8 $\mathrm{T}$ cell that can independently mediate autoimmune diabetes development in the complete absence of CD4 T cell helper functions. J Immunol 164: 3913-3918

28. Wang B, Gonzalez A, Benoist C, Mathis D (1996) The role of $\mathrm{CD}^{+} \mathrm{T}$ cells in the initiation of insulin-dependent diabetes mellitus. Eur J Immunol 26: 1762-1769

29. Cook JR, Solheim JC, Connolly JM, Hansen TH (1995) Induction of peptide-specific $\mathrm{CD}^{+} \mathrm{CTL}$ clones in $\beta 2$ microglobulin-deficient mice. J Immunol 154: 47-57

30. Serreze DV, Chapman HD, Varnum DS, Gerling I, Leiter EH, Shultz LD (1997) Initiation of autoimmune diabetes in NOD/Lt mice is MHC class I-dependent. J Immunol 158: 3978-3986

31. DiLorenzo TP, Graser RT, Ono T et al. (1998) Major histocompatibility complex class I-restricted $\mathrm{T}$ cells are required for all but the end stages of diabetes development in nonobese diabetic mice and use a prevalent $\mathrm{T}$ cell receptor $\alpha$ chain gene rearrangement. Proc Natl Acad Sci U S A 95: 12538-12543

32. Oschilewski U, Kiesel U, Kolb H (1985) Administration of silica prevents diabetes in BB-rats. Diabetes 34: 197-199

33. Hutchings P, Rosen H, O'Reilly L, Simpson E, Gordon S, Cooke A (1990) Transfer of diabetes in mice prevented by blockade of adhesion-promoting receptor on macrophages. Nature 348: 639-642

34. Serreze DV, Gaedeke JW, Leiter EH (1993) Hematopoietic stem-cell defects underlying abnormal macrophage development and maturation in NOD/Lt mice: defective regulation of cytokine receptors and protein kinase $\mathrm{C}$. Proc Natl Acad Sci U S A 90: 9625-9629

35. Piganelli JD, Martin T, Haskins K (1998) Splenic macrophages from the NOD mouse are defective in the ability to present antigen. Diabetes 47: 1212-1218

36. Noorchashm H, Noorchashm N, Kern J, Rostami SY, Barker CF, Naji A (1997) B-cells are required for the initiation of insulitis and sialitis in nonobese diabetic mice. Diabetes 46: 941-946

37. Jansen A, Homo-Delarche F, Hooijkaas H, Leenen PJ, Dardenne M, Drexhage HA (1994) Immunohistochemical characterization of monocytes-macrophages and dendritic cells involved in the initiation of the insulitis and beta- cell destruction in NOD mice. Diabetes 43: 667-675

38. Jun HS, Yoon CS, Zbytnuik L, van Rooijen N, Yoon JW (1999) The role of macrophages in T cell-mediated autoimmune diabetes in nonobese diabetic mice. $\mathrm{J}$ Exp Med 189: 347-358

39. Jun HS, Santamaria P, Lim HW, Zhang ML, Yoon JW (1999) Absolute requirement of macrophages for the development and activation of $\beta$-cell cytotoxic $\mathrm{CD}^{+}$T-cells in T-cell receptor transgenic NOD mice. Diabetes 48 : 34-42

40. Balasa B, Krahl T, Patstone G et al. (1997) CD40 ligandCD40 interactions are necessary for the initiation of insulitis and diabetes in nonobese diabetic mice. J Immunol 159: 4620-4627

41. Kolb-Bachofen V, Kolb H (1989) A role for macrophages in the pathogenesis of type 1 diabetes. Autoimmunity 3: $145-154$

42. Wong FS, Visintin I, Wen L, Flavell RA, Janeway CA Jr (1996) CD8 T cell clones from young nonobese diabetic (NOD) islets can transfer rapid onset of diabetes in NOD mice in the absence of CD4 cells. J Exp Med 183: $67-76$ 
43. Seewaldt S, Thomas HE, Ejrnaes M et al. (2000) Virus-induced autoimmune diabetes: most $\beta$-cells die through inflammatory cytokines and not perforin from autoreactive (anti-viral) cytotoxic T-lymphocytes. Diabetes 49: 1801-1809

44. Amrani A, Verdaguer J, Anderson B, Utsugi T, Bou S, Santamaria P (1999) Perforin-independent $\beta$-cell destruction by diabetogenic $\mathrm{CD}^{+} \mathrm{T}$ lymphocytes in transgenic nonobese diabetic mice. J Clin Invest 103: 1201-1209

45. Amrani A, Verdaguer J, Thiessen S, Bou S, Santamaria P (2000) IL- $1 \alpha$, IL- $1 \beta$, and IFN- $\gamma$ mark $\beta$-cells for Fas-dependent destruction by diabetogenic $\mathrm{CD}^{+} \mathrm{T}$ lymphocytes. J Clin Invest 105: 459-468

46. von Herrath MG, Oldstone MB (1997) Interferon- $\gamma$ is essential for destruction of $\beta$ cells and development of insulin-dependent diabetes mellitus. J Exp Med 185: 531-539

47. Ludewig B, Odermatt B, Landmann S, Hengartner H, Zinkernagel RM (1998) Dendritic cells induce autoimmune diabetes and maintain disease via de novo formation of local lymphoid tissue. J Exp Med 188: 1493-1501

48. Kreuwel HT, Morgan DJ, Krahl T, Ko A, Sarvetnick N, Sherman LA (1999) Comparing the relative role of perforin/granzyme versus Fas/Fas ligand cytotoxic pathways in $\mathrm{CD}^{+} \mathrm{T}$ cell-mediated insulin-dependent diabetes mellitus. J Immunol 163: 4335-4341

49. Herrera PL, Harlan DM, Vassalli P (2000) A mouse CD8 T cell-mediated acute autoimmune diabetes independent of the perforin and Fas cytotoxic pathways: possible role of membrane TNF. Proc Natl Acad Sci U S A 97: 279-284

50. Kägi D, Odermatt B, Seiler P, Zinkernagel RM, Mak TW, Hengartner H (1997) Reduced incidence and delayed onset of diabetes in perforin-deficient nonobese diabetic mice. J Exp Med 186: 989-997

51. Yamada K, Takane-Gyotoku N, Yuan X, Ichikawa F, Inada C, Nonaka K (1996) Mouse islet cell lysis mediated by interleukin-1-induced Fas. Diabetologia 39: 1306-1312

52. Suarez-Pinzon W, Sorensen O, Bleackley RC, Elliott JF, Rajotte RV, Rabinovitch A (1999) $\beta$-cell destruction in NOD mice correlates with Fas (CD95) expression on $\beta$ cells and proinflammatory cytokine expression in islets. Diabetes 48: 21-28

53. Suarez-Pinzon WL, Power RF, Rabinovitch A (2000) Fas ligand-mediated mechanisms are involved in autoimmune destruction of islet beta cells in non-obese diabetic mice. Diabetologia 43: 1149-1156

54. Chervonsky AV, Wang Y, Wong FS et al. (1997) The role of Fas in autoimmune diabetes. Cell 89: 17-24

55. Itoh N, Imagawa A, Hanafusa Tet al. (1997) Requirement of Fas for the development of autoimmune diabetes in nonobese diabetic mice. J Exp Med 186: 613-618

56. Kang SM, Schneider DB, Lin Z et al. (1997) Fas ligand expression in islets of Langerhans does not confer immune privilege and instead targets them for rapid destruction. Nat Med 3: 738-743

57. Su X, Hu Q, Kristan JM et al. (2000) Significant role for Fas in the pathogenesis of autoimmune diabetes. J Immunol 164: 2523-2532

58. Thomas HE, Darwiche R, Corbett JA, Kay TW (1999) Evidence that $\beta$ cell death in the nonobese diabetic mouse is Fas independent. J Immunol 163: 1562-1569

59. Allison J, Strasser A (1998) Mechanisms of $\beta$-cell death in diabetes: a minor role for CD95. Proc Natl Acad Sci U S A 95: $13818-13822$

60. Pakala SV, Chivetta M, Kelly CB, Katz JD (1999) In autoimmune diabetes the transition from benign to pernicious insulitis requires an islet cell response to tumor necrosis factor $\alpha$. J Exp Med 189: 1053-1062
61. Kim S, Kim KA, Hwang DY et al. (2000) Inhibition of autoimmune diabetes by Fas ligand: the paradox is solved. J Immunol 164: 2931-2936

62. Kägi D, Ho A, Odermatt B, Zakarian A, Ohashi PS, Mak TW (1999) TNF receptor 1 -dependent $\beta$ cell toxicity as an effector pathway in autoimmune diabetes. J Immunol 162: 4598-4605

63. Guerder S, Picarella DE, Linsley PS, Flavell RA (1994) Costimulator B7-1 confers antigen-presenting-cell function to parenchymal tissue and in conjunction with tumor necrosis factor $\alpha$ leads to autoimmunity in transgenic mice. Proc Natl Acad Sci U S A 91: 5138-5142

64. Sarvetnick N, Liggitt D, Pitts SL, Hansen SE, Stewart TA (1988) Insulin-dependent diabetes mellitus induced in transgenic mice by ectopic expression of class II MHC and interferon-gamma. Cell 52: 773-782

65. Stewart TA, Hultgren B, Huang X, Pitts-Meek S, Hully J, MacLachlan NJ (1993) Induction of type I diabetes by interferon- $\alpha$ in transgenic mice. Science 260: 1942-1946

66. Allison J, Malcolm L, Chosich N, Miller JF (1992) Inflammation but not autoimmunity occurs in transgenic mice expressing constitutive levels of interleukin-2 in islet beta cells. Eur J Immunol 22: 1115-1121

67. DiCosmo BF, Picarella D, Flavell RA (1994) Local production of human IL-6 promotes insulitis but retards the onset of insulin-dependent diabetes mellitus in non-obese diabetic mice. Int Immunol 6: 1829-1837

68. Higuchi Y, Herrera P, Muniesa P et al. (1992) Expression of a tumor necrosis factor $\alpha$ transgene in murine pancreatic $\beta$ cells results in severe and permanent insulitis without evolution towards diabetes. J Exp Med 176: 1719-1731

69. Picarella DE, Kratz A, Li CB, Ruddle NH, Flavell RA (1992) Insulitis in transgenic mice expressing tumor necrosis factor $\beta$ (lymphotoxin) in the pancreas. Proc Natl Acad Sci U S A 89: 10036-10040

70. Wogensen L, Huang X, Sarvetnick N (1993) Leukocyte extravasation into the pancreatic tissue in transgenic mice expressing interleukin 10 in the islets of Langerhans. J Exp Med 178: 175-185

71. Grewal IS, Grewal KD, Wong FS, Picarella DE, Janeway CA Jr, Flavell RA (1996) Local expression of transgene encoded TNF $\alpha$ in islets prevents autoimmune diabetes in nonobese diabetic (NOD) mice by preventing the development of auto-reactive islet-specific T cells. J Exp Med 184: 1963-1974

72. Green EA, Eynon EE, Flavell RA (1998) Local expression of TNF $\alpha$ in neonatal NOD mice promotes diabetes by enhancing presentation of islet antigens. Immunity 9: 733-743

73. Green EA, Flavell RA (2000) The temporal importance of TNF $\alpha$ expression in the development of diabetes. Immunity 12: 459-469

74. Allison J, McClive P, Oxbrow L, Baxter A, Morahan G, Miller JF (1994) Genetic requirements for acceleration of diabetes in non-obese diabetic mice expressing interleukin-2 in islet $\beta$-cells. Eur $\mathrm{J}$ Immunol 24: 2535-2541

75. Mueller R, Krahl T, Sarvetnick N (1996) Pancreatic expression of interleukin-4 abrogates insulitis and autoimmune diabetes in nonobese diabetic (NOD) mice. J Exp Med 184: 1093-1099

76. Gallichan WS, Balasa B, Davies JD, Sarvetnick N (1999) Pancreatic IL-4 expression results in islet-reactive Th2 cells that inhibit diabetogenic lymphocytes in the nonobese diabetic mouse. J Immunol 163: 1696-1703

77. Wogensen L, Lee MS, Sarvetnick N (1994) Production of interleukin 10 by islet cells accelerates immune-mediated 
destruction of $\beta$ cells in nonobese diabetic mice. J Exp Med 179: 1379-1384

78. Leiter EH, Christianson GJ, Serreze DV, Ting AT, Worthen SM (1989) MHC antigen induction by interferon- $\gamma$ on cultured mouse pancreatic $\beta$ cells and macrophages. Genetic analysis of strain differences and discovery of an "occult" class I-like antigen in NOD/Lt mice. J Exp Med 170: $1243-1262$

79. Thomas HE, Parker JL, Schreiber RD, Kay TW (1998) IFN- $\gamma$ action on pancreatic $\beta$ cells causes class I MHC upregulation but not diabetes. J Clin Invest 102: 1249-1257

80. Wogensen L, Molony L, Gu D, Krahl T, Zhu S, Sarvetnick N (1994) Postnatal anti-interferon- $\gamma$ treatment prevents pancreatic inflammation in transgenic mice with $\beta$-cell expression of interferon- $\gamma$. J Interferon Res 14: 111-116

81. Gysemans C, Pavlovic D, Bouillon R, Eizirik DL, Mathieu C (2001) Dual role of interferon- $\gamma$ signaling pathway in sensitivity of pancreatic beta cells to immune destruction. Diabetologia 44: 567-574

82. Hultgren B, Huang X, Dybdal N, Stewart TA (1996) Genetic absence of $\gamma$-interferon delays but does not prevent diabetes in NOD mice. Diabetes 45: 812-817

83. Wang B, Andre I, Gonzalez A et al. (1997) Interferon- $\gamma$ impacts at multiple points during the progression of autoimmune diabetes. Proc Natl Acad Sci U S A 94: 13844-13849

84. Serreze DV, Post CM, Chapman HD, Johnson EA, Lu B, Rothman PB (2000) Interferon- $\gamma$ receptor signaling is dispensable in the development of autoimmune type 1 diabetes in NOD mice. Diabetes 49: 2007-2011

85. Trembleau S, Penna G, Gregori S et al. (1999) Pancreasinfiltrating Th1 cells and diabetes develop in IL-12-deficient nonobese diabetic mice. J Immunol 163: 2960-2968

86. Radu DL, Noben-Trauth N, Hu-Li J, Paul WE, Bona CA (2000) A targeted mutation in the IL- $4 \mathrm{R} \alpha$ gene protects mice against autoimmune diabetes. Proc Natl Acad Sci U S A 97: 12700-12704

87. Wang B, Gonzalez A, Höglund P, Katz JD, Benoist C, Mathis D (1998) Interleukin-4 deficiency does not exacerbate disease in NOD mice. Diabetes 47: 1207-1211

88. Kanagawa O, Xu G, Tevaarwerk A, Vaupel BA (2000) Protection of nonobese diabetic mice from diabetes by gene(s) closely linked to IFN-gamma receptor loci. J Immunol 164: 3919-3923

89. Falcone M, Yeung B, Tucker L, Rodriguez E, Krahl T, Sarvetnick N (2001) IL-4 triggers autoimmune diabetes by increasing self-antigen presentation within the pancreatic islets. Clin Immunol 98: 190-199

90. Steinman L (1997) Some misconceptions about understanding autoimmunity through experiments with knockouts. J Exp Med 185: 2039-2041

91. Mandrup-Poulsen T, Bendtzen K, Nielsen JH, Bendixen G, Nerup J (1985) Cytokines cause functional and structural damage to isolated islets of Langerhans. Allergy 40: 424-429

92. Eizirik DL, Pavlovic D (1997) Is there a role for nitric oxide in $\beta$-cell dysfunction and damage in IDDM? Diabetes Metab Rev 13: 293-308

93. Hoorens A, Pipeleers D (1999) Nicotinamide protects human beta cells against chemically-induced necrosis, but not against cytokine-induced apoptosis. Diabetologia 42: $55-59$

94. Pavlovic D, Chen MC, Gysemans CA, Mathieu C, Eizirik DL (1999) The role of interferon regulatory factor-1 in cytokine-induced mRNA expression and cell death in murine pancreatic $\beta$-cells. Eur Cytokine Netw 10: 403-412
95. Liu D, Pavlovic D, Chen MC, Flodstrom M, Sandler S, Eizirik DL (2000) Cytokines induce apoptosis in $\beta$-cells isolated from mice lacking the inducible isoform of nitric oxide synthase (iNOS-/-). Diabetes 49: 1116-1122

96. Hoorens A, Stange G, Pavlovic D, Pipeleers D (2001) Distinction between interleukin-1-induced necrosis and apoptosis of islet cells. Diabetes 50: 551-557

97. Liu D, Darville M, Eizirik DL (2001) Double-stranded RNA induces $\beta$-cell Fas mRNA expression and increases cytokine-induced $\beta$-cell apoptosis. Endocrinology 142: 2593-2599

98. Zumsteg U, Frigerio S, Hollander GA (2000) Nitric oxide production and Fas surface expression mediate two independent pathways of cytokine-induced murine beta-cell damage. Diabetes 49: 39-47

99. Saldeen J (2000) Cytokines induce both necrosis and apoptosis via a common bcl-2-inhibitable pathway in rat insulin-producing cells. Endocrinology 141: 2003-2010

100. Cetkovic-Cvrlje M, Eizirik DL (1994) TNF- $\alpha$ and IFN- $\gamma$ potentiate the deleterious effects of IL-1 beta on mouse pancreatic islets mainly via generation of nitric oxide. Cytokine 6: 399-406

101. Corbett JA, Sweetland MA, Wang JL, Lancaster JR Jr, McDaniel ML (1993) Nitric oxide mediates cytokine-induced inhibition of insulin secretion by human islets of Langerhans. Proc Natl Acad Sci U S A 90: 1731-1735

102. Eizirik DL, Sandler S, Welsh N et al. (1994) Cytokines suppress human islet function irrespective of their effects on nitric oxide generation. J Clin Invest 93: 1968-1974

103. Rabinovitch A, Suarez-Pinzon WL, Strynadka K et al. (1994) Human pancreatic islet $\beta$-cell destruction by cytokines is independent of nitric oxide production. J Clin Endocrinol Metab 79: 1058-1062

104. Delaney CA, Pavlovic D, Hoorens A, Pipeleers DG, Eizirik DL (1997) Cytokines induce deoxyribonucleic acid strand breaks and apoptosis in human pancreatic islet cells. Endocrinology 138: 2610-2614

105. Welsh N, Margulis B, Borg LA et al. (1995) Differences in the expression of heat-shock proteins and antioxidant enzymes between human and rodent pancreatic islets: implications for the pathogenesis of insulin-dependent diabetes mellitus. Mol Med 1: 806-820

106. Burkart V, Liu H, Bellmann K et al. (2000) Natural resistance of human beta cells toward nitric oxide is mediated by heat shock protein 70. J Biol Chem 275: 19521-19528

107. Jaattela M (1999) Heat shock proteins as cellular lifeguards. Ann Med 31: 261-271

108. Jun HS, Yoon JW (2001) The role of viruses in Type I diabetes: two distinct cellular and molecular pathogenic mechanisms of virus-induced diabetes in animals. Diabetologia 44: 271-285

109. Roivainen M, Rasilainen S, Ylipaasto P et al. (2000) Mechanisms of Coxsackievirus-induced damage to human pancreatic $\beta$-cells. J Clin Endocrinol Metab 85: 432-440

110. Jacobs BL, Langland JO (1996) When two strands are better than one: the mediators and modulators of the cellular responses to double-stranded RNA. Virology 219: 339-349

111. Rhodes CJ, Taylor KW (1985) Effect of interferon and double-stranded RNA on $\beta$-cell function in mouse islets of Langerhans. Biochem J 228: 87-94

112. Heitmeier MR, Scarim AL, Corbett JA (1999) Doublestranded RNA inhibits $\beta$-cell function and induces islet damage by stimulating $\beta$-cell production of nitric oxide. J Biol Chem 274: 12531-12536

113. Sch $\varnothing d t$ M, Ludvigsen L, Andersen NA, Mandrup-Poulsen T (2001) Protein kinase R (PKR) is upregulated by cyto- 
kines in rat islets and RIN-cells. Diabetes Metab: A 097 (Abstract)

114. Blair LA, Heitmeier MR, Scarim AL, Maggi LB Jr, Corbett JA (2001) Double-stranded RNA-dependent protein kinase is not required for double-stranded RNA-induced nitric oxide synthase expression or nuclear factor- $x \mathrm{~B}$ activation by islets. Diabetes 50: 283-290

115. Scarim AL, Arnush M, Blair LA et al. (2001) Mechanisms of beta-cell death in response to double-stranded (ds) RNA and interferon-gamma: dsRNA-dependent protein kinase apoptosis and nitric oxide-dependent necrosis. Am J Pathol 159: 273-283

116. Cheshire JL, Williams BR, Baldwin AS Jr (1999) Involvement of double-stranded RNA-activated protein kinase in the synergistic activation of nuclear factor- $\varkappa \mathrm{B}$ by tumor necrosis factor- $\alpha$ and $\gamma$-interferon in preneuronal cells. J Biol Chem 274: 4801-4806

117. Bonnet MC, Weil R, Dam E, Hovanessian AG, Meurs EF (2000) PKR stimulates NF- $\mathrm{KB}$ irrespective of its kinase function by interacting with the $\mathrm{I} \varkappa \mathrm{B}$ kinase complex. Mol Cell Biol 20: 4532-4542

118. Dinarello CA (1997) Interleukin-1. Cytokine Growth Factor Rev 8: 253-265

119. Dupraz P, Cottet S, Hamburger F, Dolci W, Felley-Bosco E, Thorens B (2000) Dominant negative MyD88 proteins inhibit interleukin- $\beta$ /interferon- $\gamma$-mediated induction of nuclear factor $\varkappa \mathrm{B}$-dependent nitrite production and apoptosis in $\beta$ cells. J Biol Chem 275: 37672-37678

120. Gilmore TD (1999) The Rel/NF- $x \mathrm{~B}$ signal transduction pathway: introduction. Oncogene 18: 6842-6844

121. Reddy SA, Huang JH, Liao WS (1997) Phosphatidylinositol 3-kinase in interleukin 1 signaling. Physical interaction with the interleukin 1 receptor and requirement in NF $x$ B and AP-1 activation. J Biol Chem 272: 29167-29173

122. Auron PE (1998) The interleukin 1 receptor: ligand interactions and signal transduction. Cytokine Growth Factor Rev 9: 221-237

123. Tau G, Rothman P (1999) Biologic functions of the IFN- $\gamma$ receptors. Allergy 54: 1233-1251

124. Stephanou A, Brar BK, Scarabelli TM et al. (2000) Ischemia-induced STAT-1 expression and activation play a critical role in cardiomyocyte apoptosis. J Biol Chem 275: 10002-10008

125. Stark GR, Kerr IM, Williams BR, Silverman RH, Schreiber RD (1998) How cells respond to interferons. Annu Rev Biochem 67: 227-264

126. Rath PC, Aggarwal BB (1999) TNF-induced signaling in apoptosis. J Clin Immunol 19: 350-364

127. Saklatvala J, Dean J, Finch A (1999) Protein kinase cascades in intracellular signalling by interleukin-I and tumour necrosis factor. Biochem Soc Symp 64: 63-77

128. Whitmarsh AJ, Davis RJ (1996) Transcription factor AP-1 regulation by mitogen-activated protein kinase signal transduction pathways. J Mol Med 74: 589-607

129. Davis RJ (2000) Signal transduction by the JNK group of MAP kinases. Cell 103: 239-252

130. Wesselborg S, Bauer MK, Vogt M, Schmitz ML, SchulzeOsthoff K (1997) Activation of transcription factor NF$\varkappa \mathrm{B}$ and p38 mitogen-activated protein kinase is mediated by distinct and separate stress effector pathways. J Biol Chem 272: 12422-12429

131. Larsen CM, Wadt KA, Juhl LF et al. (1998) Interleukin$1 \beta$-induced rat pancreatic islet nitric oxide synthesis requires both the p38 and extracellular signal-regulated kinase 1/2 mitogen-activated protein kinases. J Biol Chem 273: $15294-15300$
132. Andersen NA, Larsen CM, Mandrup-Poulsen T (2000) $\mathrm{TNF} \alpha$ and IFN $\gamma$ potentiate IL- $\beta$ induced mitogen activated protein kinase activity in rat pancreatic islets of Langerhans. Diabetologia 43: 1389-1396

133. Pavlovic D, Andersen NA, Mandrup-Poulsen T, Eizirik DL (2000) Activation of extracellular signal-regulated kinase (ERK)1/2 contributes to cytokine-induced apoptosis in purified rat pancreatic $\beta$-cells. Eur Cytokine Netw 11: 267-274

134. Welsh N (1996) Interleukin-1 $\beta$-induced ceramide and diacylglycerol generation may lead to activation of the c-Jun NH2-terminal kinase and the transcription factor ATF-2 in the insulin-producing cell line RINm5F. J Biol Chem 271: 8307-8312

135. Ammendrup A, Maillard A, Nielsen K et al. (2000) The c-Jun amino-terminal kinase pathway is preferentially activated by interleukin-1 and controls apoptosis in differentiating pancreatic beta-cells. Diabetes 49: 1468-1476

136. Bonny C, Oberson A, Steinmann M, Schorderet DF, Nicod P, Waeber G (2000) IB1 reduces cytokine-induced apoptosis of insulin-secreting cells. J Biol Chem 275: 16466-16472

137. Bonny C, Oberson A, Negri S, Sauser C, Schorderet DF (2001) Cell-permeable peptide inhibitors of JNK: novel blockers of beta-cell death. Diabetes 50: 77-82

138. Sprinkel AME, Andersen NAA, Mandrup-Poulsen T (2001) Glucose potentiates IL- $\beta$-induced p38 mitogenactivated protein kinase activity in rat pancreatic islets of Langerhans. Eur Cytokine Netw 12: 331-336

139. Binzer J, Andersen NA, Størling J, Mandrup-Poulsen T (2001) Interleukin-1-beta induced p38 and c-jun-N-terminal kinase activities in isolated rat pancreatic islets is nitric oxide dependent. Diabetes Metab: A39 (Abstract)

140. Wang L, Bhattacharjee A, Zuo Z et al. (1999) A low voltage-activated $\mathrm{Ca} 2$ + current mediates cytokine-induced pancreatic beta-cell death. Endocrinology 140: 1200-1204

141. St $\varnothing$ rling J, Zaitsev SV, Andersen NA et al. (2001) Calcium signalling via L-Type calcium channels mediates IL-1-induced activities of C-Jun N-terminal kinase and p38 in pancreatic beta-cells. Diabetologia 44 [Supp 1]: A129 (Abstract)

142. Lipshutz RJ, Fodor SP, Gingeras TR, Lockhart DJ (1999) High density synthetic oligonucleotide arrays. Nat Genet 21: $20-24$

143. Lockhart DJ, Winzeler EA (2000) Genomics, gene expression and DNA arrays. Nature 405: 827-836

144. Celis JE, Kruhøffer M, Gromova I et al. (2000) Gene expression profiling: monitoring transcription and translation products using DNA microarrays and proteomics. FEBS Lett 480: 2-16

145. Cardozo AK, Kruhøffer M, Ørntoft T, Eizirik DL (2000) Identification of novel IL- $1 \beta$ induced genes in pancreatic $\beta$-cells by high density oligonucleotide arrays. Diabetologia 43: A75 (Abstract)

146. Cardozo AK, Kruhøffer M, Leeman R, Ørntoft T, Eizirik DL (2001) Identification of novel cytokine induced genes in pancreatic $\beta$-cells by high density oligonucleotide arrays. Diabetes 50: 909-920

147. Rieneck K, Bovin LF, Josefsen K, Buschard K, Svenson M, Bendtzen K (2000) Massive parallel gene expression profiling of RINm5F pancreatic islet $\beta$-cells stimulated with interleukin-1 $\beta$. APMIS 108: 855-872

148. John NE, Andersen HU, Fey SJ et al. (2000) Cytokine- or chemically derived nitric oxide alters the expression of proteins detected by two-dimensional gel electrophoresis in neonatal rat islets of Langerhans. Diabetes 49: 1819-1829 
149. Mose Larsen P, Fey SJ, Larsen MR et al. (2001) Proteome analysis of IL- $1 \beta$ induced changes in protein expression in rat islets of Langerhans. Diabetes 50: 1056-1063

150. Pahl HL (1999) Activators and target genes of Rel/NF- $x \mathrm{~B}$ transcription factors. Oncogene 18: 6853-6866

151. Tak PP, Firestein GS (2001) NF- $\varkappa$ B: a key role in inflammatory diseases. J Clin Invest 107: 7-11

152. Mattson MP, Camandola S (2001) NF- $\varkappa$ B in neuronal plasticity and neurodegenerative disorders. J Clin Invest 107: 247-254

153. Eizirik DL, Flodstrom M, Karlsen AE, Welsh N (1996) The harmony of the spheres: inducible nitric oxide synthase and related genes in pancreatic beta cells. Diabetologia 39: $875-890$

154. Darville MI, Eizirik DL (1998) Regulation by cytokines of the inducible nitric oxide synthase promoter in insulinproducing cells. Diabetologia 41: 1101-1108

155. Darville MI, Ho YS, Eizirik DL (2000) NF- $\varkappa$ B is required for cytokine-induced manganese superoxide dismutase expression in insulin-producing cells. Endocrinology 141: 153-162

156. Darville MI, Eizirik DL (2001) Cytokine-induction of Fas gene expression in insulin-producing cells requires the transcription factors $\mathrm{NK}-x \mathrm{~B}$ and C/EBP. Diabetes 50: $1741-1748$

157. Heimberg H, Heremans Y, Jobin C et al. (2001) Inhibition of cytokine-induced NF- $\varkappa \mathrm{B}$ activation by adenovirus-mediated expression of a nuclear factor $\chi \mathrm{B}$ super-repressor prevents $\beta$-cell apoptosis. Diabetes 50: 2219-2224

158. Giannoukakis N, Rudert WA, Trucco M, Robbins PD (2000) Protection of human islets from the effects of interleukin-1beta by adenoviral gene transfer of an $\mathrm{I} \varkappa \mathrm{B}$ repressor. J Biol Chem 275: 36509-36513

159. Baker MS, Chen X, Cao XC, Kaufman DB (2001) Expression of a dominant negative inhibitor of $\mathrm{NF}-x \mathrm{~B}$ protects MIN6 beta-cells from cytokine-induced apoptosis. J Surg Res 97: 117-122

160. Grey ST, Arvelo MB, Hasenkamp W, Bach FH, Ferran C (1999) A20 inhibits cytokine-induced apoptosis and nuclear factor $\varkappa \mathrm{B}$ - dependent gene activation in islets. J Exp Med 190: 1135-1146

161. Schindler C and Strehlow I (2000) Cytokines and STAT signaling. Adv Pharmacol 47: 113-174

162. Kamijo R, Harada H, Matsuyama TBM et al. (1994) Requirements for transcription factor IRF-1 in NO synthase induction in macrophages. Science 263: 1612-1615

163. Tada Y, Ho A, Matsuyama T, Mak TW (1997) Reduced incidence and severity of antigen-induced autoimmune diseases in mice lacking interferon regulatory factor-1. J Exp Med 185: 231-238

164. Suk K, Kim S, Kim YH et al. (2001) IFN- $\gamma /$ TNF- $\alpha$ synergism as the final effector in autoimmune diabetes: a key role for STAT1/IFN regulatory factor-1 pathway in pancreatic beta cell death. J Immunol 166: 4481-4489

165. Ling Z, Hannaert JC, Pipeleers D (1994) Effect of nutrients, hormones and serum on survival of rat islet beta cells in culture. Diabetologia 37: 15-21

166. Welsh N, Eizirik DL, Bendtzen K, Sandler S (1991) Interleukin- $1 \beta$-induced nitric oxide production in isolated rat pancreatic islets requires gene transcription and may lead to inhibition of the Krebs cycle enzyme aconitase. Endocrinology 129: 3167-3173

167. Eizirik DL (1988) Interleukin-1 induced impairment in pancreatic islet oxidative metabolism of glucose is potentiated by tumor necrosis factor. Acta Endocrinol (Copenh) 119: 321-325

168. Sandler S, Eizirik DL, Svensson C, Strandell E, Welsh M, Welsh N (1991) Biochemical and molecular actions of interleukin-1 on pancreatic $\beta$-cells. Autoimmunity 10: 241-253

169. Ling Z, Van de Casteele M, Eizirik DL, Pipeleers DG (2000) Interleukin- $1 \beta$-induced alteration in a $\beta$-cell phenotype can reduce cellular sensitivity to conditions that cause necrosis but not to cytokine-induced apoptosis. Diabetes 49: 340-345

170. Jonas JC, Sharma A, Hasenkamp W et al. (1999) Chronic hyperglycemia triggers loss of pancreatic beta cell differentiation in an animal model of diabetes. J Biol Chem 274: $14112-14121$

171. Pelengaris S, Khan M, Evan G (2000) Control of islet growth by $c$-myc in vivo: diabetes may be the price for avoiding cancer. Diabetologia 43: A47 (Abstract)

172. Edlund H (1998) Transcribing pancreas. Diabetes 47: 1817-1823

173. Nielsen K, Karlsen AE, Deckert M et al. (1999) Beta-cell maturation leads to in vitro sensitivity to cytotoxins. Diabetes 48: 2324-2332

174. Van de Casteele M, Heimberg H, Ling Z, Pipeleers D (2001) Cytokine-mediated apoptosis in rat $\beta$-cells is preceded by downregulation of Bcl-2 and Bax-omega expression. Diabetes 49: S82 (Abstract)

175. Piro S, Lupi R, Dotta F et al. (2001) Bovine islets are less susceptible than human islets to damage by human cytokines. Transplantation 71: 21-26

176. Loweth AC, Williams GT, Scarpello JH, Morgan NG (1997) Evidence for the involvement of cGMP and protein kinase $\mathrm{G}$ in nitric oxide-induced apoptosis in the pancreatic B-cell line, HIT-T15. FEBS Lett 400: 285-288

177. Tejedo J, Bernabe JC, Ramirez R, Sobrino F, Bedoya FJ (1999) NO induces a cGMP-independent release of cytochrome $c$ from mitochondria which precedes caspase 3 activation in insulin producing RINm5F cells. FEBS Lett 459: 238-243

178. Rabinovitch A, Suarez-Pinzon W, Strynadka K et al. (1999) Transfection of human pancreatic islets with an anti-apoptotic gene (bcl-2) protects $\beta$-cells from cytokine-induced destruction. Diabetes 48: 1223-1229

179. Cottet S, Dupraz P, Hamburger F, Dolci W, Jaquet M, Thorens B (2001) SOCS-1 protein prevents JAK/STATdependent inhibition of $\beta$ cell insulin gene transcription and secretion in response to IFN- $\gamma$. J Biol Chem 276: 25862-25870

180. Vansittant P (1992) A choice of murder. Peter Owen, London

181. Oyadamari S, Takeda K, Takiguchi M et al. (2001) Nitricoxide induced apoptosis in pancreatic $\beta$-cells is mediated by the endoplasmic reticulum stress pathway. Proc Natl Acad Sci USA 98: 10845-10850 